\title{
Hemipelagic deposits on the Mendeleev and northwestern Alpha submarine Ridges in the Arctic Ocean: acoustic stratigraphy, depositional environment and an inter-ridge correlation calibrated by the ACEX results
}

\author{
Vibeke Bruvoll • Yngve Kristoffersen • \\ Bernard J. Coakley $\cdot$ John R. Hopper
}

Received: 5 August 2009/Accepted: 23 July 2010/Published online: 24 August 2010

(C) The Author(s) 2010. This article is published with open access at Springerlink.com

\begin{abstract}
The first high resolution multichannel seismic data from the Mendeleev and Alpha Ridges in the Arctic Ocean have been used to investigate the depositional history, and compare acoustic stratigraphies of the three main sub-marine ridges (Mendeleev, Alpha and Lomonosov) in the polar ocean. Acoustic basement on the Mendeleev Ridge is covered by a $\sim 0.6-0.8 \mathrm{~s}$ thick sediment drape over highs and up to $1.8 \mathrm{~s}$ within grabens. A pronounced angular discordance at $0.18-0.23 \mathrm{~s}$ below the seafloor along the middle to upper slopes divides the succession into an upper, undisturbed, uniformly thick, hemipelagic drape (Unit M1) and a partially truncated lower unit (Unit M2) characterized by strong reflection bands. Unit M2 is thicker in intra-ridge grabens and includes three sub-units with abundant debris flows in the uppermost subunit (M2a). The discordance between Units M1 and M2 most likely relates to instability along the middle to upper slopes and mass wasting, triggered by tectonic activity. The scars were further smoothed by bottom current erosion. We observe comparable acoustic stratigraphy and discordant
\end{abstract}

\footnotetext{
V. Bruvoll $(\bowtie) \cdot$ Y. Kristoffersen

Department of Earth Science, University of Bergen, Allegate 41, 5014 Bergen, Norway

e-mail: vibeke.bruvoll@geo.uib.no

Y. Kristoffersen

e-mail: yngve.kristoffersen@geo.uib.no

B. J. Coakley

Geophysical Institute, University of Alaska, Fairbanks,

903 Koyukuk Dr., Fairbanks, AK 99775, USA

e-mail: bcoakley@gi.alaska.edu

J. R. Hopper

Geological Survey of Denmark and Greenland, Øster Voldgade 10, 1350 Copenhagen K, Denmark

e-mail: jrh@geus.dk
}

relationships on the investigated northwestern part of Alpha Ridge. Similarly, on the central Lomonosov Ridge, Paleocene and younger sediments sampled by scientific drilling include an uppermost $\sim 0.2 \mathrm{~s}$ thick drape overlying, highly reflective deposits with an angular unconformity confined to the upper slope on both sides of the ridge. Sediment instability on the three main ridges was most likely generated by a brief phase of tectonic activity ( 14.5-22 Ma), coinciding with enhanced bottom circulation. These events are coeval with the initial opening of the Fram Strait. The age of the oldest sediments above acoustic basement on the Mendeleev- and west-central Alpha Ridges is estimated to be 70-75 Ma.

Keywords Arctic Ocean - Mendeleev and Alpha Ridges · Depositional environment - Acoustic stratigraphy . Paleocirculation - Tectonics · Inter-ridge correlation

\section{Introduction}

The Arctic Ocean includes two major ocean basins; the Amerasia Basin and the Eurasia Basin (Fig. 1). Sediment thicknesses in the Amerasia Basin exceed $10 \mathrm{~km}$ (Grantz et al. 1990), and reach $\sim 2 \mathrm{~km}$ in the younger Eurasia Basin (Jokat and Micksch 2004; Glebovsky et al. 2006; Engen et al. 2009). The contribution from pelagic and hemipelagic sources as well as the energy level of ocean circulation is, to a first approximation, manifested by the thickness, geometries and acoustic reflection characteristics of the sediment accumulations on the isolated and elevated Mendeleev, Alpha and Lomonosov Ridges (Fig. 1).

To date, only the Lomonosov Ridge (Fig. 1) has been accessed by modern geophysical surveys and scientific drilling (Jokat et al. 1992; Jokat et al. 1995a; Jokat 2005; 


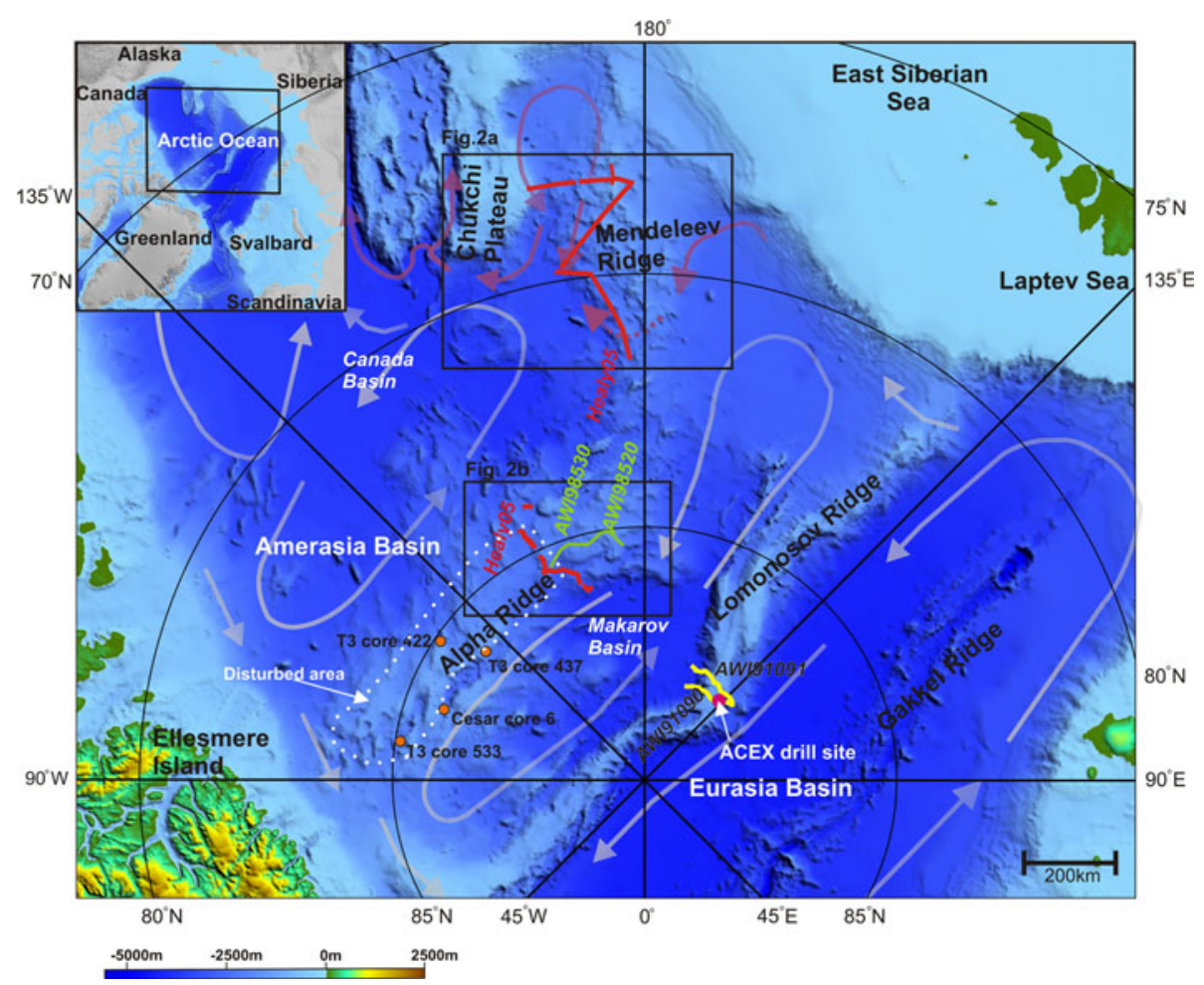

Fig. 1 Overview of the Arctic Ocean basins, ridges and continental margins. Bathymetry and land elevation are from the International Bathymetric Chart of the Arctic Ocean (IBCAO) (Jakobsson et al. 2008). Location of the study areas are marked with black boxes. Red lines indicate the seismic reflection profiles from the Healy 2005 survey used in this study, yellow lines are seismic reflection profiles AWI91090 and AWI91091 (Jokat et al. 1992) and the green lines marks the seismic reflection profiles of Jokat (2003). The pink dot marks the IODP Expedition 304, ACEX, drill site and the orange dots mark the approximate positions of the T3 and CESAR shallow cores.

Moran et al. 2006). The central part of the ridge is covered by a $\sim 0.5 \mathrm{~km}$ thick section of Cenozoic, hemipelagic sediments resting unconformably on a prograding wedge (Jokat et al. 1992; Grantz et al. 2001; Moran et al. 2006). Average Cenozoic sedimentation rates at the drill site were $\sim 1 \mathrm{~cm} / \mathrm{ka}$ with a major stratigraphic break at $200 \mathrm{~m}$ below the seafloor (18.2-44.4 Ma) (Moran et al. 2006; Backman et al. 2008; Sangiorgi et al. 2008)

We present a study of the acoustic stratigraphy of the first modern high-resolution multichannel seismic (MCS) reflection data from the Mendeleev Ridge and the northwestern part of the Alpha Ridge (Figs. 1, 2). This paper focuses upon the Late Cretaceous and Cenozoic depositional history and paleoenvironments of these ridges and their flanks. The high standing ridges have been inaccessible to turbidites from the adjacent continental margins and the basement is covered by a drape of hemipelagic sediments deposited a low energy environment. We observe ridge-wide similarities in acoustic stratigraphy as well as systematic stratal discordance along their upper flanks which makes it possible to establish a seismic
The transparent grey arrows show circulation patterns of the Atlantic Layer and Upper Polar Deepwater to depths of $1700 \mathrm{~m}$ after Jones (2001), and the purple arrows show the boundary current flow predominantly between the $1500-2000 \mathrm{~m}$ isobaths along the Mendeleev Ridge and Chukchi Plateau (Woodgate et al. 2007). The white dotted line marks the approximate areal extend of extensive seabed erosion, mass wasting and sub-bottom sediment deformation along the crest and south slope of the Alpha Ridge (Kristoffersen et al. 2009)

stratigraphic frame work, although only a set of widely spaced seismic lines are available.

Hemipelagic deposits which include the upper $0.5 \mathrm{~s}$ thick section on the Mendeleev Ridge, northwestern part of Alpha Ridge and the central part of the Lomonosov Ridge in the Arctic Ocean appears to have similar acoustic characteristics, and in particular a disconformity at $0.2 \mathrm{~s}$ sub-bottom depth spatially restricted to their respective middle to upper slopes. In this way, parts of the stratigraphic calibration provided by ACEX drilling (Moran et al. 2006) can be put in a wider polar basin perspective.

\section{Outline of the geology, paleogeography and ocean circulation of the Arctic Ocean}

Plate tectonic evolution

The submarine Lomonosov Ridge divides the Arctic Ocean into the Amerasia- and Eurasia sub-basins (Fig. 1). Seafloor spreading in a proto-Eurasia Basin was initiated in the 
Fig. 2 Bathymetric map from IBCAO (Jakobsson et al. 2008) of a the Mendeleev Ridge and b the Alpha Ridge. Red lines mark the seismic reflection profiles of the Healy 2005 survey, black dots marks the start of each seismic line and the bold red lines indicate the location of figures. The white dotted line in Fig. 2b marks the part of the study area affected by extensive seabed erosion, mass wasting and sub-bottom sediment deformation (Kristoffersen et al. 2009)

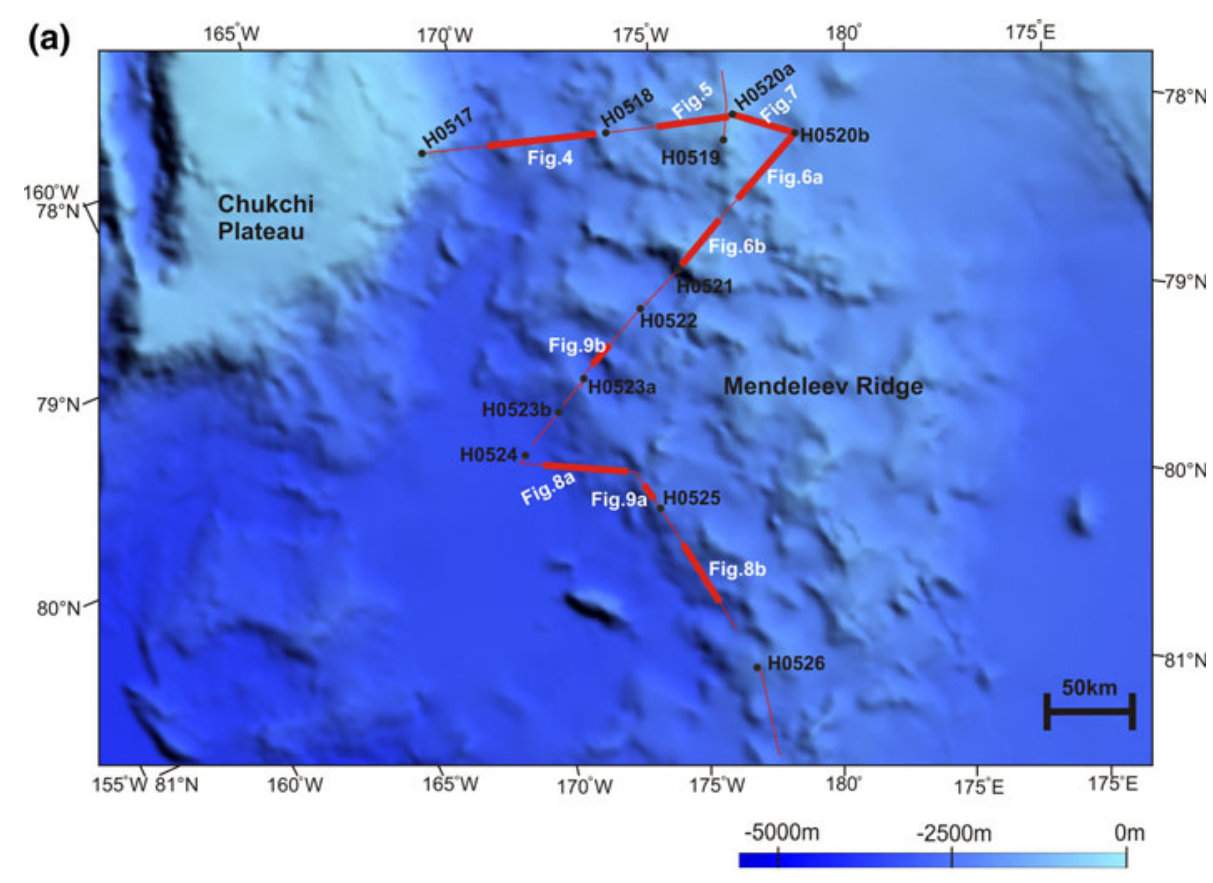

(b)

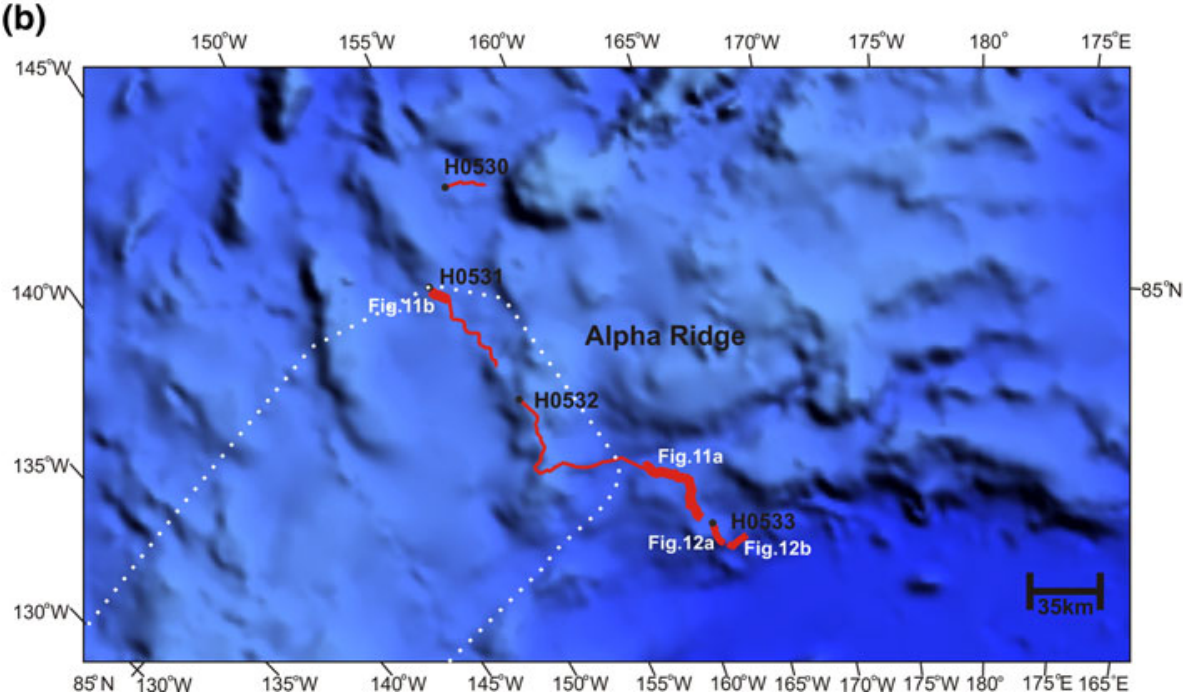

early Cenozoic with the opening of the Norwegian Greenland Sea (Karasik Karasik 1968; Talwani and Eldholm 1977; Vogt et al. 1979). Rifting between Greenland and Norway extended into the Arctic Ocean and separated a $\sim 1,700 \mathrm{~km}$ long continental sliver from the BarentsKara Sea margin (Karasik 1968; Vogt et al. 1979). This sliver became the Lomonosov Ridge which subsided below sea level in the earliest Eocene (Moran et al. 2006), but remained shallow until early Miocene (Sangiorgi et al. 2008). Further development of the Eurasia Basin was associated with seafloor spreading along the Gakkel Ridge (Karasik 1968d; Vogt et al. 1979; Eldholm et al. 1990).

Uplift of basement ridges, erosion and subsequent subsidence on the north slope of Alaska and on the Canadian
Arctic margin suggest that the Amerasia Basin evolved by rifting and seafloor spreading during Late Jurassic/Early Cretaceous (e.g. Embry 1990; Grantz et al. 1998; Lawver et al. 2002). However, the configuration of the plate boundaries involved remains controversial (Miller et al. 2006) as the geophysical data are ambiguous and plate boundaries difficult to define. The Alpha and Mendeleev Ridge complex is a broad (200-400 km) and up to $\sim 2 \mathrm{~km}$ high submarine rise, that extends across the Amerasia Basin from the continental margin north of Canada to the margin of the East Siberian Sea (Fig. 1). The deep area close to $83-84^{\circ} \mathrm{N}, 180^{\circ} \mathrm{E}$ separates the widest part of the rise, the Alpha Ridge north of Canada, from the narrower Mendeleev Ridge north of Siberia (Fig. 1). The rise 
constitutes a complex assemblage of alternating high and low standing blocks trending NE-SW at the Mendeleev Ridge (Figs. 1, 2). These structures pass into a series of NE-SW trending grabens and ridges in the western part of the Alpha Ridge and more $\mathrm{N}-\mathrm{S}$ oriented structures to the east (Fig. 1).

The origin and age of the Mendeleev and Alpha Ridges are unknown and disputed, but most investigators today favour an oceanic plateau (e.g. Van Wagoner and Williamson 1985; Forsyth et al. 1986; Jackson et al. 1986; Weber 1990; Lawver and Muller 1994; Lawver et al. 2002), or a highly attenuated continental crust (Lebedeva-Ivanova et al. 2006; Miller et al. 2006) based on the available data today.

The depositional environment

The Amerasia Basin was essentially land-locked during the Late Cretaceous. The Western Interior Seaway represented a late Albian through middle Maastrichtian shallow connection to the proto-Gulf of Mexico (Kauffman and Caldwell 1993; Sageman and Arthur 1994). A shallow marine connection to the embryonic Eurasia Basin also existed during Turonian through middle Eocene extending from the present Kara- and Laptev Sea via the Turgai area into the present Caspian Sea and the Tethys Ocean (Baraboshkin et al. 2003). Glimpses of the Late Cretaceous/ Early Cenozoic paleoenvironment of the Amerasia Basin are represented by short cores from the western part of the Alpha Ridge (Fig. 1). Core 437 from the western part of the ridge contains Campanian-Paleocene biosiliceous oozes representing seasonal upwelling conditions (Dell'Agnese and Clark 1994). CESAR core 6 also includes a biosiliceous unit of Maastrichtian-Paleocene age (Mudie et al. 1986). Black mud of Maastrichtian age in core 533 with a high abundance of amorphous marine matter was probably deposited in a shelf to upper slope environment with high paleoproductivity (Firth and Clark 1998). All cores suggest upwelling conditions during the Mastrichtian into the Paleocene (Kitchell and Clark 1982; Dell'Agnese and Clark 1994; Firth and Clark 1998), and biosiliceous ooze in core 422 may be as young as middle-late Eocene or Oligocene (Bukry 1984; Mudie et al. 1986).

The central flat topped area of the Lomonosov Ridge from $87^{\circ} 30^{\prime}-88^{\circ} \mathrm{N}$ has a $\sim 0.5 \mathrm{~s}$, uniformly thick, sediment cover, resting unconformably on dipping strata (Jokat et al. 1992, 1995a). Scientific drilling at this location during the Integrated Ocean Drilling Program (IODP) Expedition 302, the Arctic Coring Expedition (ACEX) (Moran et al. 2006) provides a paleoenvironmental and key stratigraphic tie point. The drilling recovered a $420 \mathrm{~m}$ long composite section of Cenozoic sediments comprising three different units: Unit 1-an upper $220 \mathrm{~m}$ thick section of glaciomarine clay ranging from middle Eocene to the present including a hiatus (18.2-44.4 Ma); Unit 2-biosiliceous-rich silty clay to ooze (220-318 mbsf) of Middle to early Eocene age; and Unit 3-early Eocene to Middle Palaeocene hard silty clay to mudstone resting unconformably on Late Cretaceous shallow water sands (404.7-427.6 mbsf) (Moran et al. 2006). The unconformity between the Late Cretaceous shallow water sand and Tertiary marine strata was correlated to the angular unconformity LR-3 observed in the seismic reflection data (Jokat et al. 1995a).

\section{Paleoceanography}

Microfossils in the drill cores document an early Eocene Arctic Ocean characterized by a stratified water column (Stein et al. 2006; Stickley et al. 2008) with warm $\left(\sim 18^{\circ} \mathrm{C}\right.$ ), relatively fresh surface waters (Sluijs et al. 2006; Waddell and Moore 2008) and intermittent connection to the surrounding oceans (Gleason et al. 2009). At the time of the Paleocene-Eocene Thermal Event $(\sim 55.5 \mathrm{Ma})$, a change in the carbon/sulfur ratio, recorded by the occurrence of pyrite and fine lamination in the sediments, indicate euxinic water masses from epipelagic depths (0-200 m) up to the photic zone (Sluijs et al. 2006; Stein et al. 2006). Sediments characteristic of euxinic conditions were recovered from below (subunit 1/6) as well as above (subunit 1/5) the 44.4 Ma-18.2 Ma hiatus and may suggest oxygen deficient conditions throughout that entire interval (Backman and Moran 2009). A return to fully oxygenated conditions is represented by dark brown sediments above the uppermost grey layer dated as younger than $17.5 \mathrm{Ma}$ (Jakobsson et al. 2007). This change to oxygenated conditions has been linked to the opening of the Fram Strait and the establishment of a tele-connection between the water masses of the Arctic Ocean and the North Atlantic (Jakobsson et al. 2007).

\section{Ocean circulation}

The present Arctic Ocean has strong vertical stratification of the water column in its upper part. A well mixed surface layer (20-50 m thick) lies above a region of constant temperature, but increasing salinity to a depth of 150-200 m (Jones 2001). These upper layers isolate the warmer, more saline waters of Atlantic origin below and inhibit melting of the sea ice cover. The oceanic circulation in the present Arctic Ocean is characterized by low kinetic energy and weak cyclonic boundary currents (Rudels et al. 1994; Jones 2001; Woodgate et al. 2007). The boundary current flow (Fig. 1) is predominantly between the 1,500-2,000 $\mathrm{m}$ isobaths along the flanks of the Lomonosov Ridge, the Mendeleev Ridge and along the Chukchi Rise 
(Woodgate et al. 2007). Observed bottom current velocities are $<1 \mathrm{~cm} / \mathrm{s}$ in water depths below $3,000 \mathrm{~m}$ and $4-6 \mathrm{~cm} / \mathrm{s}$ in the 2,000-3,000 $\mathrm{m}$ depth range on the south slope of the Mendeleev Ridge (Hunkins et al. 1960, 1969). Water masses in the Eurasia Basin are renewed from the Norwegian-Greenland seas through the Fram Strait gateway, as well as by cold, salty water from the Barents Shelf formed by brine rejection during the formation of sea ice (Aagaard et al. 1985). The Atlantic layer crosses the Lomonosov Ridge into the Canadian Basin from the Siberian continental margin northwards to $<88^{\circ} \mathrm{N}$ at velocities of $1 \sim 5^{\circ} \mathrm{cm} / \mathrm{s}$ (Woodgate et al. 2001). Ventilation of the deep Canada Basin occurs by water spilling over the Lomonosov Ridge threshold from Eurasia Basin (Jones et al. 1995; Jones 2001) and from downslope convection of saltier water formed by cooling and freezing on the shelves (Aagaard et al. 1981, 1985). The time scale for renewal of bottom water in the Canada Basin is $\sim 300-500$ years (Aagaard and Carmack 1994; Jones et al. 1995).

The data base and understanding of the present day general circulation pattern and energy level in the Arctic Ocean is increasing. Our knowledge of the paleoenvironment is from seismic studies over Lomonosov Ridge (Jokat et al. 1992, 1995a, and Jokat 2005) and scientific drilling on the central, elevated part of the ridge with recovery of part of the Cenozoic section. The first modern seismic multichannel data from Mendeleev Ridge and northwestern Alpha Ridge (also Jokat 2003) presented here allow us to consider the broader perspective of the central Arctic Ocean paleoenvironment from Late Cretaceous to present.

\section{Data and methods}

During 2005, 2,200 km of MCS data were collected in the Amerasia Basin of the Arctic Ocean from the USCG icebreaker Healy, including $\sim 1,100 \mathrm{~km}$ over the Mendeleev and Alpha Ridges (Figs. 1, 2). The seismic source consisted of two 4 litre airguns suspended below a depressor plane at the end of an armoured rubber hose. The armoured hose was designed to protect the hydrophone cable and the depressor plane provided a downward force in the turbulent propeller wash. Data were recorded using a $300 \mathrm{~m}$ long analogue streamer with up to 24 active channels sampled at $2 \mathrm{~ms}$ intervals. The shot interval was $20 \mathrm{~s}$ which represented approximately $40 \mathrm{~m}$ when the vessel maintained a constant speed of 4 knots $(7.5 \mathrm{~km} / \mathrm{h})$. During acquisition, the airguns and the front of the seismic cable were frequently forced to the surface by ice blocks and streamer sections were pinched by the random motion of the ice in the wake of the ship. The result was damage to the internal wiring of the cable, loss of recording channels and ultimately loss of entire streamer sections. These problems became more severe as ice conditions worsened; over the western Alpha Ridge only 12 channels remained live.

The seismic data were acquired along crooked ship tracks with the seismic source firing at a constant time interval while the boat speed varied between 0 and 5 knots $(0-9.25 \mathrm{~km} / \mathrm{h})$. These irregularities were assimilated by a binning procedure (Gjengedal 2004) and the bin size set to $25 \mathrm{~m}$. The data were resampled to $4 \mathrm{~ms}$ and dead or very noisy traces removed. The short streamer $(300 \mathrm{~m})$ relative to the water depth $(1500-4000 \mathrm{~m})$ limited processing options. A simple processing procedure included true amplitude gain recovery, bandpass filter (6-16-80-100), normal move-out correction (NMO), stack, Kirchoff time migration and trace mixing. Interval velocities were obtained from simultaneous sonobuoy measurements.

Breaking ice while acquiring seismic data introduced frequent large amplitude spikes within the frequency band of reflected energy. Noise spikes degrade the data and leads to abundant random "smiles" in the migrated sections. Test processing indicated that the spikes could be significantly dampened with limited consequences to the relative amplitudes by applying a "weak" automatic gain control (AGC window $=1000 \mathrm{~ms}$ ) before stack. This also gave a better migration result compared to applying AGC post stack. The final processing result was compared to brute stacks, various single channel stacks, as well as data processed without AGC to ensure that none of the reflection characteristics relevant to this study where significantly changed or lost. Deconvolution was not applied to the data because of difficulties in predicting the variable source wavelet, and therefore the processed data are mixed phase. The data are plotted using the Society of Exploration Geophysicists reverse polarity standard, meaning that, for minimum phase data, an increase in acoustic impedance is displayed as a peak on the seismic waveshape (plotted in blue on the figures). All times reported here are two way travel times.

In addition to the Healy 05 (H05) seismic lines from Mendeleev and northwestern Alpha Ridges, a part of the AWI91090 seismic line from the Lomonosov Ridge (Jokat et al. 1992) has also been used in this study. Bathymetric data from IBCAO (International Bathymetric chart of the Arctic Ocean) (Jakobsson et al. 2008) provide the regional morphological context.

\section{Seismic characteristics of the deposits of the Mendeleev and Alpha Ridges}

\section{The Mendeleev Ridge}

The ridge crest is covered by a $0.6-0.8 \mathrm{~s}$ thick section of acoustically stratified sediments which drape or locally 

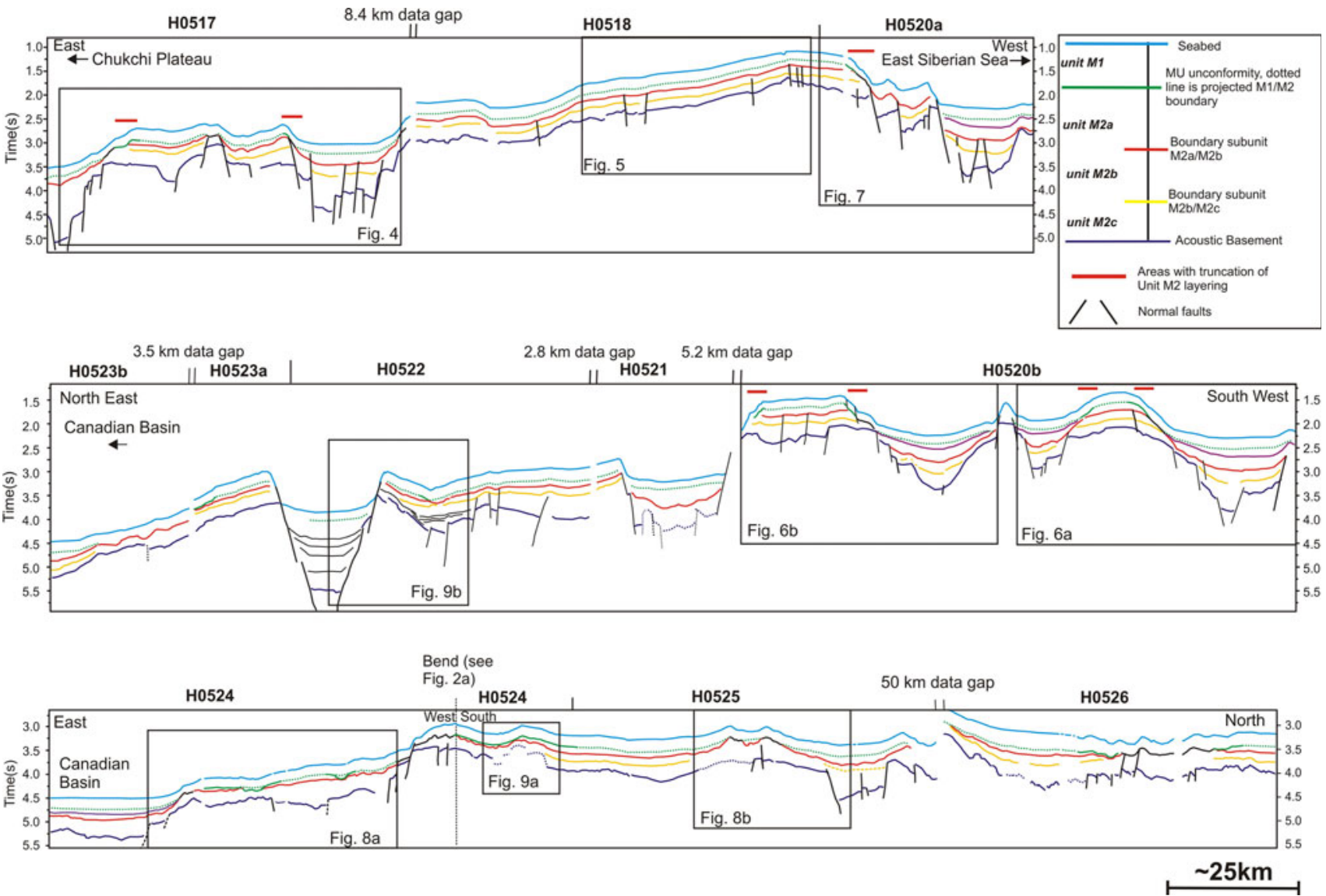

Fig. 3 Line drawings of key reflections, the MU unconformity and unit boundaries for seismic profiles H0517-20a, 20b-23b and 24-26 over the Mendeleev Ridge

onlap distinct high amplitude reflections defined as acoustic basement (e.g. Figs. 3, 4, 5). The thickness of deposits in intra-ridge grabens reaches $1.8 \mathrm{~s}$. The sedimentary succession is divided into two main units, M1 (upper) and M2 (lower) and is separated by an angular unconformity (the MU unconformity) confined to the flanks of the topographic highs (Figs. 3, 4, 6). The Unit MU disconformity can be projected upslope from either side of a basement high into a single correlative conformable surface below the level crest (Fig. 6). The contact between units M1 and M2 in the grabens is defined as a continuation of the base of the draping Unit M1 along parallel reflections.

\section{Unit MI}

The uppermost unit (M1) forms a 0.18-0.23 s thick, almost completely undisturbed, continuous drape of medium amplitude, parallel reflections. The drape is observed over the entire ridge complex (Figs. 4, 5, 6, 7) with only minor pinch-outs and onlaps at a few locations (e.g. Fig 6a, upper panel). There are also rare occurrences of local slumps
(Fig. 6b). The drape appears conformable with the underlying strata over the highs and within the grabens, but truncates Unit M2 below the upper slopes with a very distinct angular discordance between the base of M1 and the layering of subunit M2a and locally subunit M2b (Figs. 4, 6, 7).

\section{The MU unconformity}

The discordance between units M1 and M2 along the middle to upper slopes of bathymetric highs occurs as smooth truncations of laterally uniform internal layering (4, 6 and 7), as a staircase pattern of small displaced blocks in Unit M2 (e.g. Fig 4, lower panel) and also as a irregular contact (Figs. 4, lower panel and 7). The MU unconformity at margins of grabens merges with local unconformities within Unit M2 to form a composite surface (Figs. 4, 6, 7). Local incisions long the flanks of the Mendeleev Ridge cut into both subunits M2a and M2b (Fig. 8). These erosional scars are filled with either chaotic or onlapping sediments. The acoustic stratification below the scars is chaotic to subparallel and subunit M2a is locally absent (Fig. 8b). 


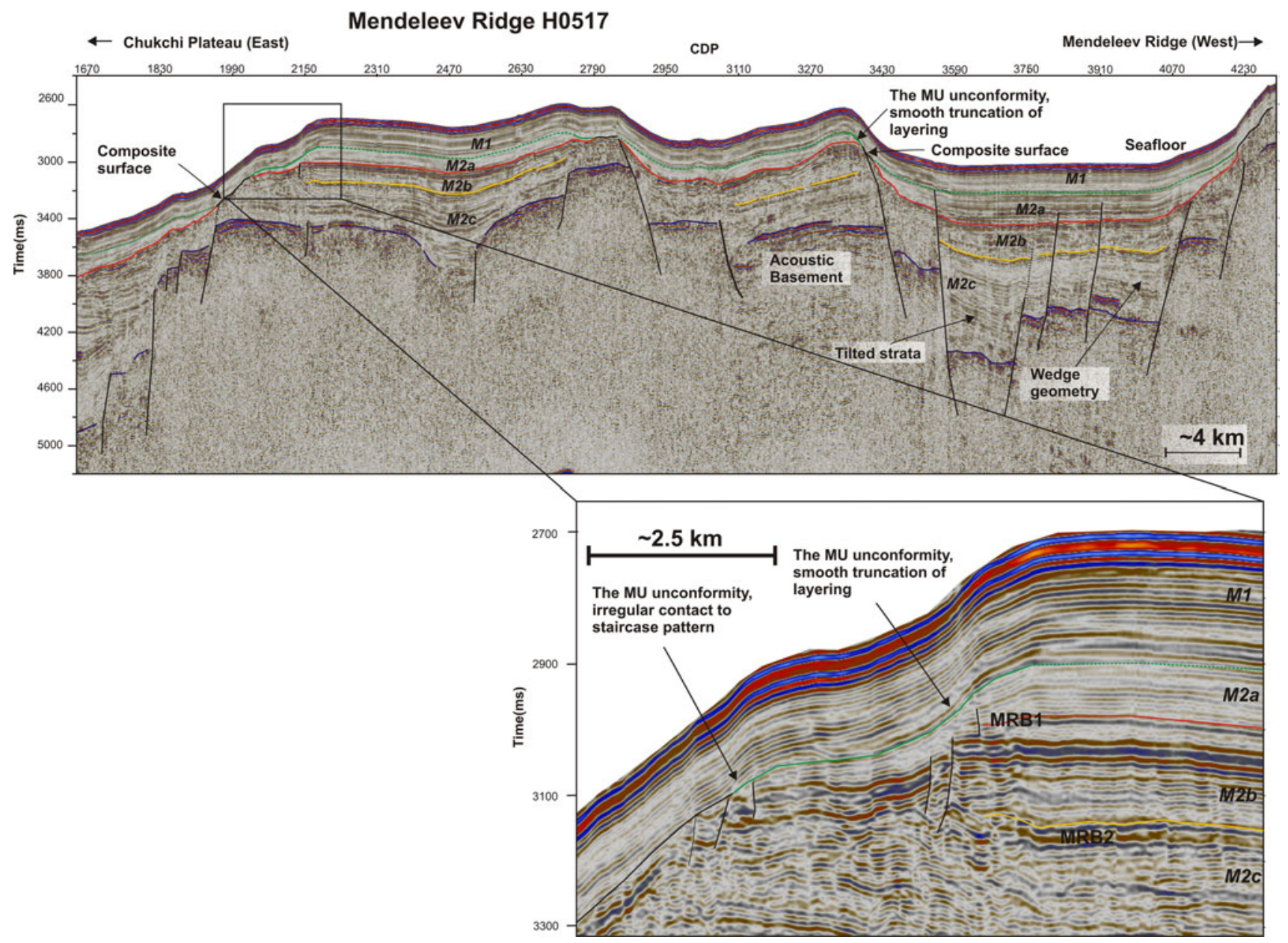

Fig. 4 Section of seismic reflection profile H0517 perpendicular to the trend of the Mendeleev Ridge (for location see Figs. 2a, 3). The bold green line shows the MU unconformity. The dotted green line marks the projected surface of the unconformity dividing the sediment section into units M1 and M2. The red line marks the top of subunit M2b, and the yellow line the top of subunit M2c. MRB1

\section{Unit M2}

Unit M2 rests on acoustic basement and is between 0.4 and 0.6 s thick over the bathymetric highs (Figs 4, 5, 6) and up to $\sim 1.5 \mathrm{~s}$ thick in the deepest grabens (Fig 3). Internal reflections are parallel and continuous on the highs where the basement is flat lying or sloping gently, but have a more complex geometry on the slopes and in the grabens (Figs. 4, 5, 7). Unit M2 can be further divided into three subunits based on reflectivity and geometry.

\section{Subunit $M 2 a$}

The acoustic image of subunit M2a over basement highs is a $0.10-0.15 \mathrm{~s}$ thick well stratified sequence of low impedance contrasts (Figs. 5, 6). Subunit M2a is conformable with the overlying Unit M1 below the crests, but and MRB2 are Mendeleev Ridge reflection band 1 and 2 respectively. Black lines indicate areas where the MU unconformity and local unconformities have merged into one composite surface. The dark blue line marks the top of the strong reflections here designated as acoustic basement and the black sub-vertical lines indicate normal faults. Notice the tilted strata and local wedge geometry

is truncated on the upper flanks of basement highs (Figs. 3, $4,6)$. The reflection characteristics and geometry is more complex in grabens and at the margin of the Canada Basin; the subunit is thicker (up to $0.48 \mathrm{~s}$ ) and a local unconformity is observed and merge upslope with the MU unconformity (Figs. 6, 7, 8a). This local graben unconformity is observed as a strong reflection onlapped by the overlying sediments (Figs. 6, 7). The upper part of subunit M2a includes an interval with convex-up/mounded geometry (Figs 6b, 7) and a transparent to discontinuous signatures (Figs. 6, 7), while the lower part of subunit M2a is dominated by high amplitude reflections.

\section{Subunit $M 2 b$}

Subunit M2b is characterized by high amplitude, parallel reflections capped by an upper band of strong reflections 


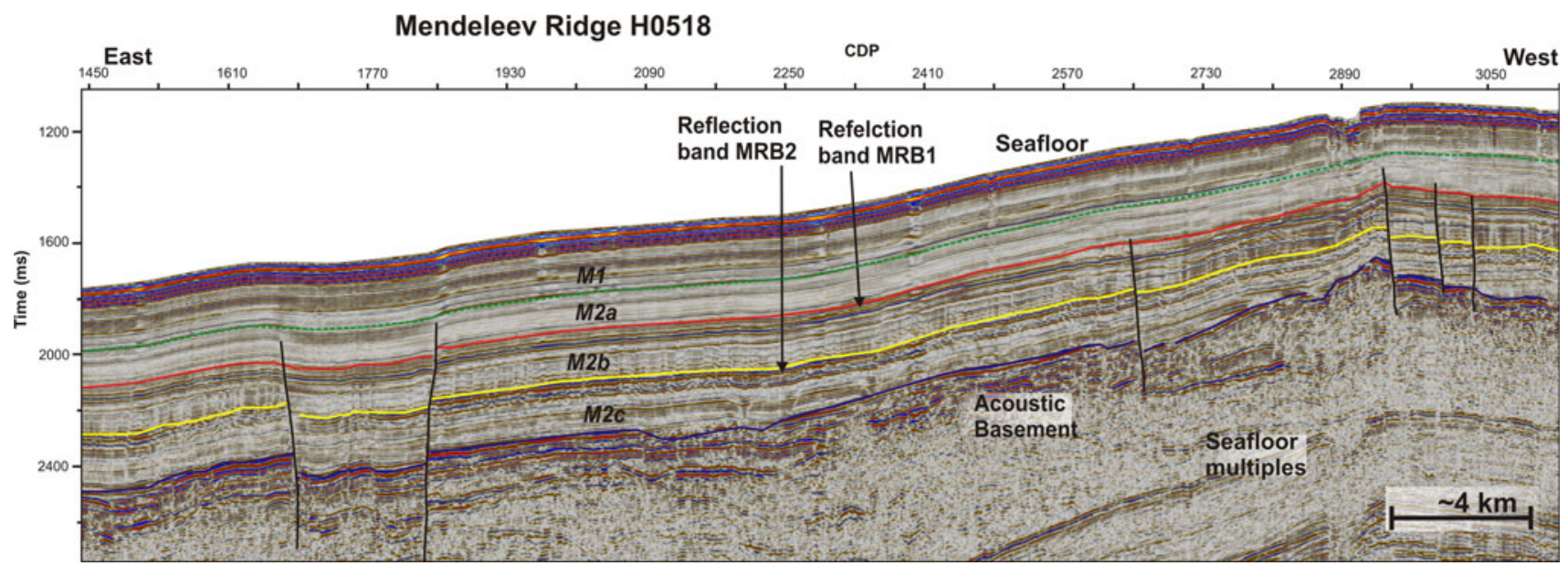

Fig. 5 Section of seismic reflection profile H0518 perpendicular to the trend of the Mendeleev Ridge over a topographical high (for location see Figs. 2a, 3). The dotted green line is the projected surface of the MU unconformity dividing the sediment section into units M1 and $\mathrm{M} 2$. The red line marks the top of subunit $\mathrm{M} 2 \mathrm{~b}$, and the yellow line the top of subunit M2c. The dark blue line marks the top of the

(MRB1) between $\sim 0.28-0.45 \mathrm{~s}$ below the sea bed (e.g. Figs. 5, 6). Sediments in the M2b interval may locally have a wavy internal stratification with a wavelength of 200-500 m and amplitude of $\sim 10 \mathrm{~ms}$ (e.g. Figs. 5, 6a, upper panel). Subunit M2b is $0.17-0.23 \mathrm{~s}$ thick over basement highs, gently dipping slopes and in grabens (Figs. 4, 5, 6, 8a). The younger subunit M2a is conformable with subunit M2b below the bathymetric highs, but onlaps subunit M2b in the grabens. This M2a/M2b discontinuity can be traced up-slope and merge with the local unconformity within subunit M2a as well as the main MU unconformity into a single composite surface (Figs 4, 6, 7). Incisions and small stratified mounds are observed at the boundary between subunits M2a and M2b along the eastern slope of Mendeleev Ridge (Fig. 8). The acoustic stratification of subunit $\mathrm{M} 2 \mathrm{~b}$ and underlying strata along the same slope are partly obliterated by mound-shaped occurrences of amplitude blanking extending from acoustic basement to the top of M2b (Fig. 9a). The sediment continuity is disrupted around these features and the acoustic basement in this area is chaotic to transparent.

\section{Subunit M2c}

The top of the unit is marked by a double-cycle reflection (MRB2 at $\sim 0.45-0.55 \mathrm{~s}$ below the sea bed) which is well defined below topographic highs and gently dipping slopes, but only locally present at deeper levels within the grabens. The MRB2 reflection band has a wavy signature several places with similar dimensions as observed in M2b (e.g. Figs. 5, 6a, upper panel). Subunit M2c is well stratified and concordant with the acoustic basement on basement highs strong reflections here designated as acoustic basement, and the black sub-vertical lines indicate normal faults. Also notice the clear expression of reflection band MRB1 and MRB2, and the wavy to undulating signature within the lower part of subunit $\mathrm{M} 2 \mathrm{~b}$ and reflection band MR2B

and gentle slopes (e.g. Figs. 4, 5,6) but onlaps basement on the steeper slopes and graben walls (e.g. Fig. 4). The contact between subunits M2c and M2b is generally conformable on the highs and gently dipping slopes, but discordant in grabens, where M2c is onlapped by M2b (e.g. Fig. 6). Subunit M2c is about $0.17-0.22 \mathrm{~s}$ thick over the topographical highs and $0.25-0.55 \mathrm{~s}$ thick in the intra-ridge grabens and lows. Maximum thickness is $0.68 \mathrm{~s}$ in the deep grabens between the Chukchi Plateau and Mendeleev Ridge (Fig. 4). A few examples of wedge geometries and weakly tilted sediment packages are present in the lower parts of some grabens (e.g. Figs. 4, 7).

\section{Faults}

Numerous offsets are present in the acoustic basement and many continue into the sediment section. Fault displacements in the sediment section are similar or less than the corresponding displacements in the acoustic basement. Almost all the faults appear to terminate below Unit M1 at the top of reflective subunit M2b or within Unit M2a (Fig. 3). The wedge shaped geometry observed in subunit M2c (Fig. 7) and weakly dipping sediment packages (Fig. 4) are associated with fault block rotation. Block rotation is also observed where the young part of Unit M2c is onlapping the rotated conformable lower part of the same unit (Fig. 9b).

The northwestern part of the Alpha Ridge

The crestal region of the western section of the Alpha Ridge (Jokat 2003) (Fig. 1), as well as its north slope (Figs $1,2 \mathrm{~b}$ ), are covered by a more than $0.6 \mathrm{~s}$ thick 
Fig. 6 a, b Two sections of seismic reflection profile H0520b from the top of Mendeleev Ridge (for location see Figs. 2a, 3). The green line marks the MU unconformity, with its projected surface (dotted line), dividing the sediment section into units M1 and M2. Notice the smooth truncation of the upper Unit M2 sediments at the flanks of topographical highs. The dotted black line marks the local graben unconformity within unit M2a. Notice the local downlap and convex up geometry in subunit M2a (Fig. 6b). The red line marks the top of subunit $\mathrm{M} 2 \mathrm{~b}$, and the yellow line the top of subunit M2c. MRB1 and MRB2 mark the Mendeleev Ridge reflection band 1 and 2 respectively. Black lines indicate areas where the MU unconformity and local unconformities have merged into one composite surface. The dark blue line marks the top of the strong reflections here designated as acoustic basement and the sub-vertical black lines indicate normal faults
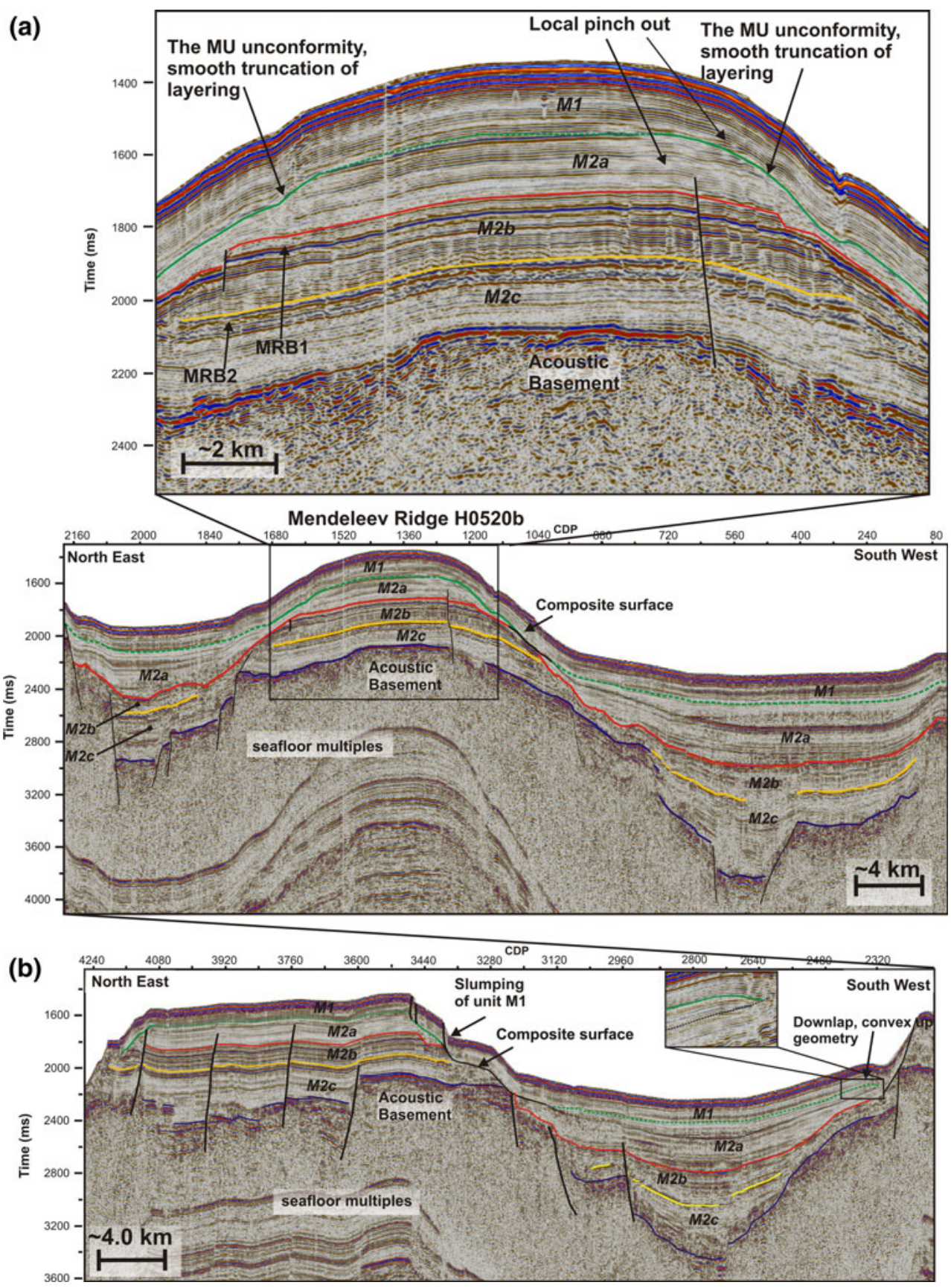

undisturbed sediment drape (Figs.10, 11a). However, east of about $160^{\circ} \mathrm{W}$ the seabed becomes uneven, the sediment section thins and the stratigraphic continuity is disrupted over a distance of $+60 \mathrm{~km}$ on the upper southern slope of the ridge (Figs.10, 11b). This disturbance is observed in different seismic surveys and appears to be part of a larger area of extensive seabed erosion, mass wasting and subbottom sediment deformation extending eastwards along the crest and south slope of the Alpha Ridge (Kristoffersen et al. 2009) (Figs. 1, 2b). Several normal faults offset acoustic basement and the overlying sediments, locally extending up to the disturbed sections (Fig. 11b).
The undisturbed areas of the northwestern Alpha Ridge are only covered by part of seismic line H0532 near the ridge crest (Figs. 10, 11a) and a short line (H0533) along the ridge flank (Figs. 10, 12). The acoustic stratigraphy of the sediment cover on Alpha Ridge is broadly similar to the undisturbed areas of the Mendeleev Ridge; an upper 0.22-0.25 s uniform package of parallel medium amplitude reflections (Unit A1, Fig. 11a) and a more reflective, 0.5-0.8 s thick, lower part (Unit A2, Fig. 11a). Unit A1 drapes and locally onlaps the truncated layering of Unit A2 (the AU unconformity) below the slope towards the Makarov Basin (Fig. 12). A minor intra-Unit A1 unconformity is manifested 


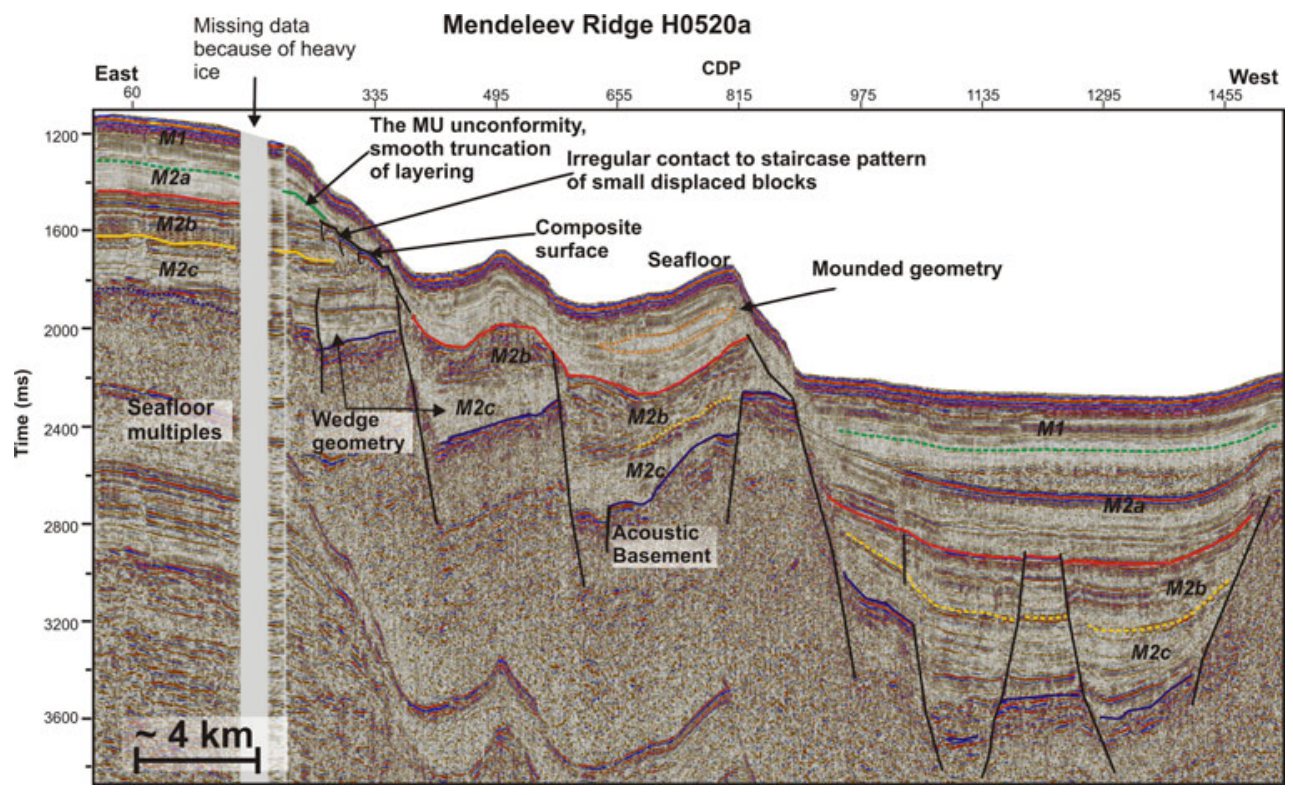

Fig. 7 Section of seismic reflection profile H0520a from the top of Mendeleev Ridge (for location see Figs. 2a, 3). Green line is the MU unconformity, with its projected surface (dotted line) dividing the sediment section into units M1 and M2. Notice the smooth truncation of the upper Unit M2 sediments at the flank of the topographical highs. The dotted black line marks the local graben unconformity within unit M2a. The red line marks the top of subunit M2b, and the yellow line the top of subunit M2c. The yellow line is dotted where

by onlap onto a stronger reflection on the slope and in a local low (Fig. 12). The lower Unit A2 may be divided into three subunits based on onlap and the presence of three high amplitude acoustic reflection bands (Fig. 11a). The double reflections (ARB1) at $\sim 0.25 \mathrm{~s}$ below the sea floor mark the top of subunit A2a. The lower part of this unit forms a continuous drape and appears conformable with the underlying strata except at two locations where it onlaps subunit A2b (Fig. 11a). A band of strong reflections (ARB2) at $\sim 0.35 \mathrm{~s}$ below seafloor marks the top of subunit $\mathrm{A} 2 \mathrm{~b}$. The contact with subunit $\mathrm{A} 2 \mathrm{c}$, associated with a second strong persistent double reflection (ARB3) at $\sim 0.53$ s below seafloor, is conformable except for minor onlap. The seismic amplitudes below the ARB3 reflection band are smaller and the strata drape or locally onlap acoustic basement. No stratigraphic offsets are observed in the sediment section in this area.

\section{Interpretation of the depositional environment at the Mendeleev and Alpha Ridges}

The upper draping units $\mathrm{M} 1$ and A1

The sediment cover on the top of the southern Mendeleev Ridge and the western Alpha Ridge show rather similar interpretation of the boundary is less certain. Black lines indicate areas where the MU unconformity and local unconformities have merged into one composite surface. The dark blue line marks the top of the strong reflections here designated as acoustic basement, and the sub-vertical black lines indicate normal faults. Notice the local mounded geometry in one of the grabens and wedge geometry in lower subunit M2c

acoustic reflection patterns and no systematic variation in thickness $(\sim 0.65-0.85 \mathrm{~s})$ (Figs. 3, 5, 10, 11a) which suggests broadly similar depositional environments. The upper Unit M1 forms a completely undisturbed drape $(0.18-0.23 \mathrm{~s}$ thick) over both high and low areas across the entire Mendeleev Ridge. The elevated ridge has been isolated from terrigenous input except for the suspended clay-fraction carried within the bottom nepheloid layer (Hunkins et al. 1969), and Unit M1 is interpreted to be a hemipelagic deposit. The thickness and acoustic characteristics of the upper Unit A1 on the north flank of the western Alpha Ridge are comparable to the observations of Unit M1 from the Mendeleev Ridge (Figs. 5, 11a), and Unit A1 is similarly considered a hemipelagic deposit.

The uniform thickness and absence of any pronounced reflector pinch-out/erosion suggests that the bottom circulation was sluggish, potentially similar to the present day bottom current velocities of $4-6 \mathrm{~cm} / \mathrm{s}$ (Hunkins et al. 1969).

The nature of the MU- and AU unconformities

The discordance between Unit M1 and Unit M2 (the MU unconformity) along the middle to upper slopes of bathymetric highs on the Mendeleev Ridge represents truncation of laterally uniform internal layering in Unit M2 and varies 

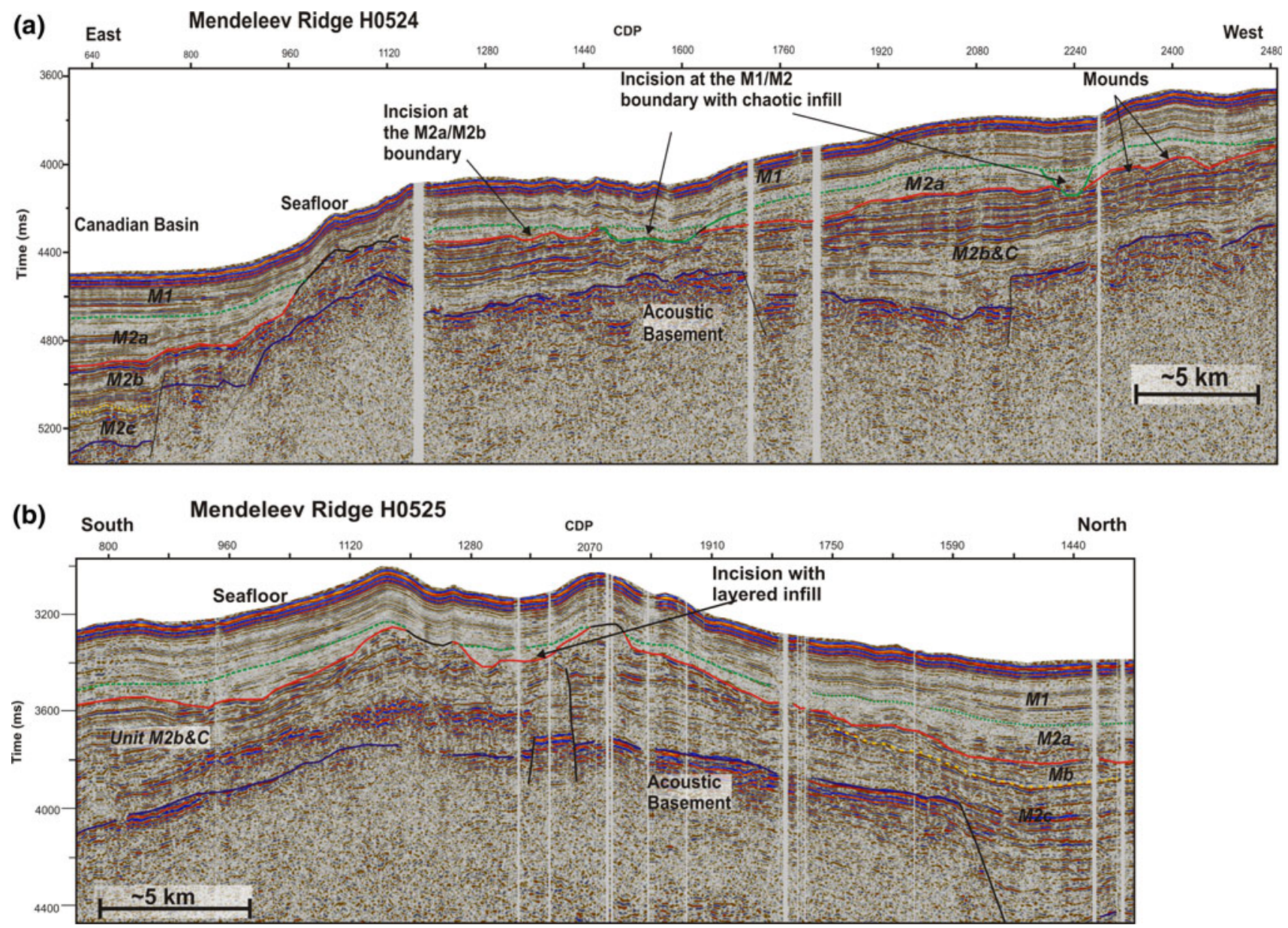

Fig. 8 Section of seismic line H0524 a across the outer slopes of the Mendeleev Ridge and b section of profile H0525 collected along the slope the Mendeleev Ridge (for location see Figs.2a, 3). The green line marks the MU unconformity, with its projected surface (dotted line), dividing the sediment section into units $\mathrm{M} 1$ and $\mathrm{M} 2$. The dotted black line marks the local graben unconformity within unit M2a. The

between a smooth surface, a irregular transition and a staircase block pattern at various scales. Post-depositional removal of sediments is indicated by abrupt truncations rather than by tapered internal layers (except one locality at the bottom of Unit M1 and in subunit M2a, Fig. 6a, upper panel). Other evidence of sediment removal is the local incisions in Unit M2 on the eastern slope of Mendeleev Ridge and the small mounds which probably represent erosional remanents (Fig. 8). On the northwestern Alpha Ridge, sediment disturbance in the crestal areas obscure the contact between units A1 and A2 (Figs. 10, 11b), but Unit A2 is truncated on the north flank of the ridge (the AU unconformity) in a similar manner as Unit M2 on the Mendeleev Ridge (Figs. 10, 12).

Removal of sediments may result from either mass wasting event(s) on unstable slopes or from bottom current erosion over time. Local undercutting of slopes by bottom current erosion, the presence of gas/gas hydrates (e.g. red line marks the top of subunit $\mathrm{M} 2 \mathrm{~b}$, and the yellow line the top of subunit M2c. Notice the rough incised surface of the MU unconformity and at the boundary between subunits M2a and M2b. The dark blue line marks the acoustic basement and the sub-vertical black lines indicate normal faults

Nixon and Grozic 2006; Esmerode et al. 2008) or loading events such as earthquakes, tides or sea level changes can all trigger slope instability. Failed sediments can produce a surface of progressively disintegrated blocks (Kvalstad et al. 2005), a process critically dependent on the degree of strain softening after failure (Gauer et al. 2005). On the Mendeleev Ridge the chaotic to staircase blocky pattern of the disconformity at the slopes affecting very limited part of the sediment succession in depth, aswell as the locally rough incised appearance suggests sediment removal by local mass wasting events. Evidence of related deposits is evident within the upper part of the underlying Unit M2 within grabens, particularly the upper subunit M2a (Figs. 4, 6, 7, 8)

Unit M2 on the Mendeleev Ridge forms a uniform, 0.4-0.6 s thick, drape over acoustic basement highs, and thickens to $0.8-1.4 \mathrm{~s}$ in intervening grabens. The complex stratigraphies in the grabens mostly represent infill of 
Fig. 9 a Section of H0524 (for location see Figs. 2a,3) where the sediment section is disturbed from basement to the top of subunit $\mathrm{M} 2 \mathrm{~b}$ in relation to chaotic to transparent basement highs (orange arrows). The green dotted line marks the M1/ M2 boundary and the red line is the top of M2b. b Section of seismic line $\mathrm{H} 0522$ (for location see Figs.2a, 3) showing block rotation where the upper part of subunit M2c is onlapping the rotated conformable lower part of the same unit. The green dotted line marks the M1/M2 boundary. The red line marks the top of subunit M2b, and the yellow line the top of subunit M2c. The dark blue line marks the acoustic basement and the sub-vertical black lines indicate normal faults
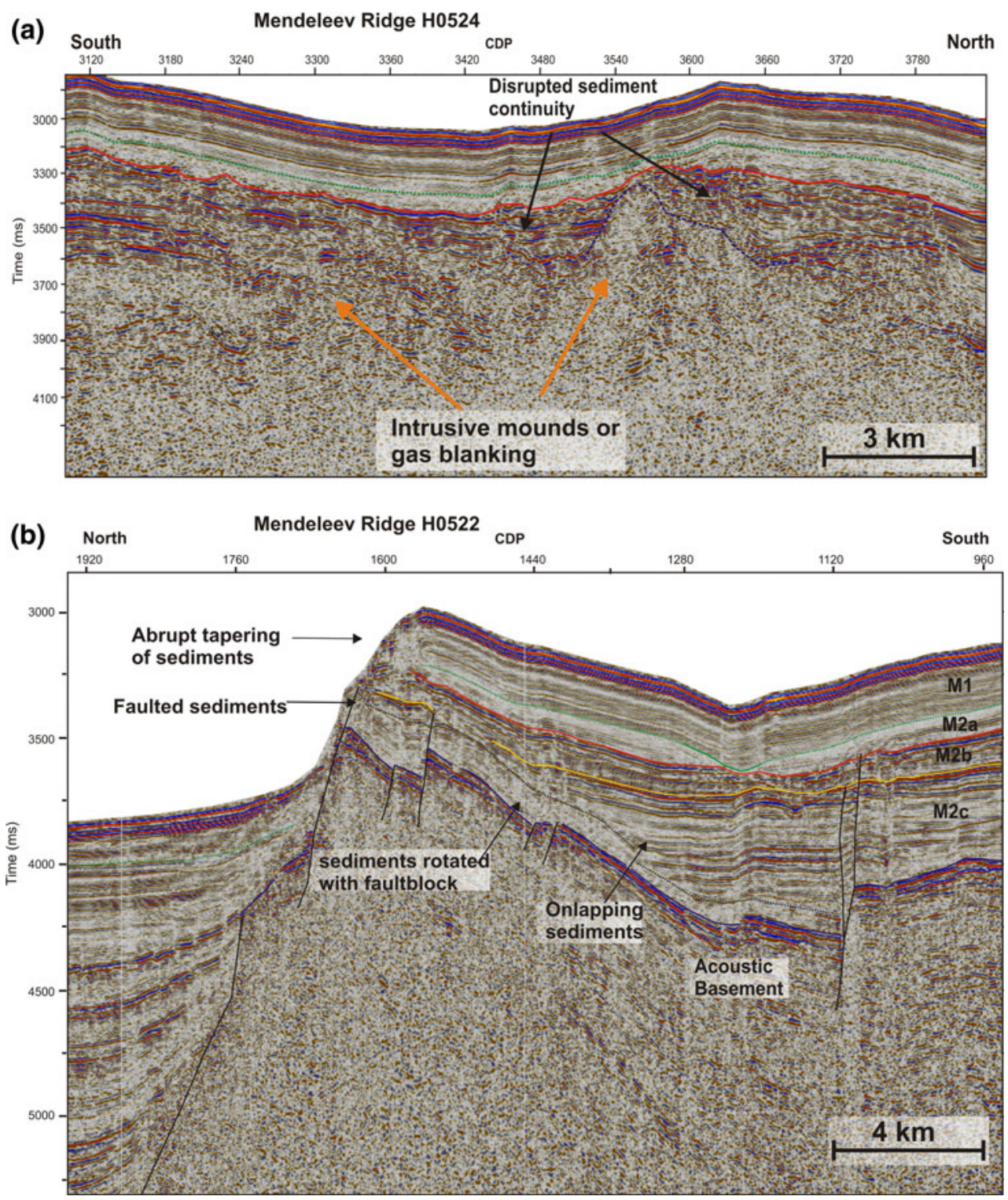

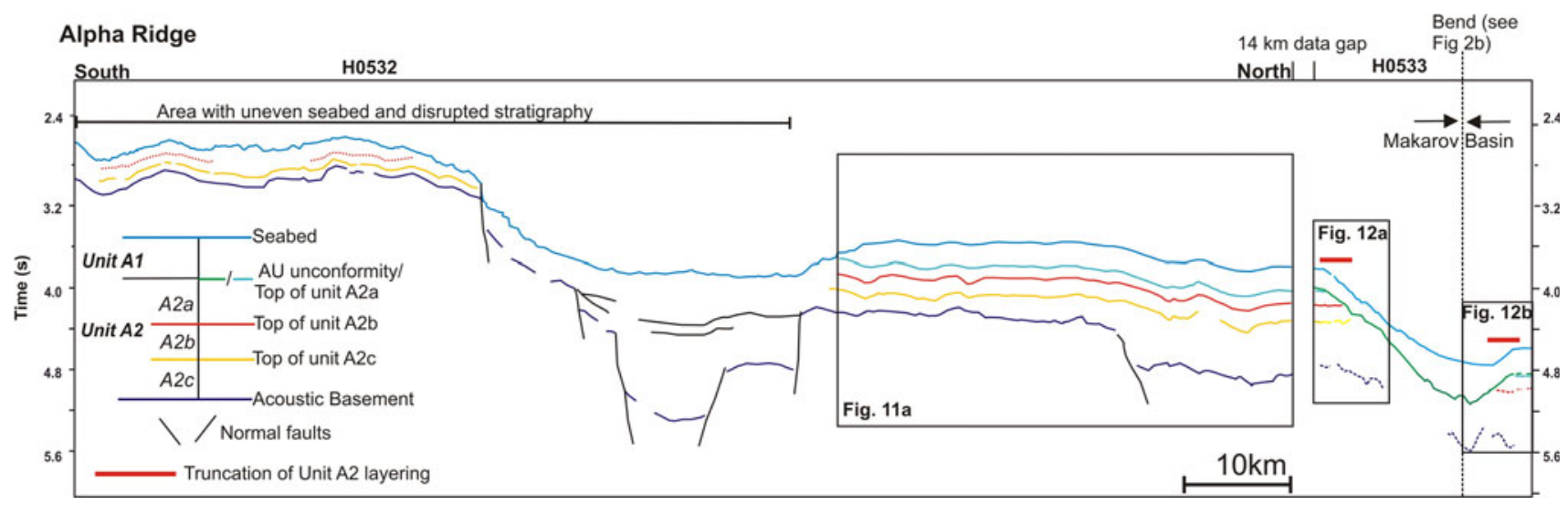

Fig. 10 Line drawings of the seafloor, the AU unconformity, key reflections and units of the seismic lines H0532 and H0533 over the Alpha Ridge, for location see Fig. $2 b$ 

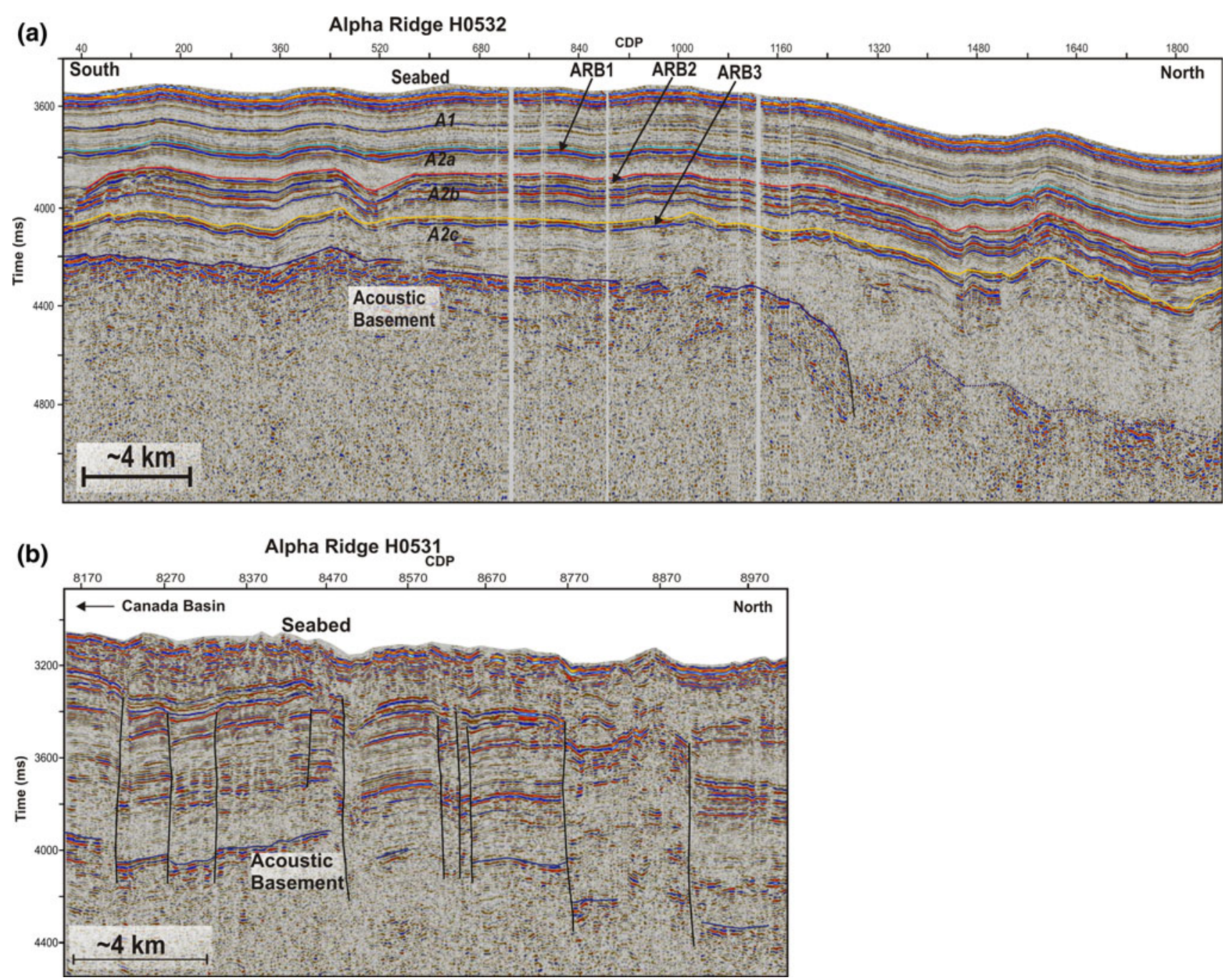

Fig. 11 a Section of profile H0532 traversing an undisturbed area of the Alpha Ridge (for location see Fig. 2b, 10). The turquoise line marks the boundary between Unit A1 and the more reflective Unit A2. This line also marks the top of subunit A2a. The red line marks the top of subunit $\mathrm{A} 2 \mathrm{~b}$ and the yellow line the top of subunit A2c. ARB1, ARB2 and ARB3 mark the Alpha Ridge reflection band 1, 2, 3,

bathymetric lows (e.g. Figs. 4, 6). Up-slope onlap from rapid infill is particular pronounced in the uppermost subunit M2a. Subunit M2a are characterized by discontinuous to continuous reflections grading upwards into a more transparent acoustic signature (Figs. 6, 7). The discontinuous reflection patterns are interpreted as debris from proximal larger mass wasting episodes where internal layering was partly destroyed (e.g. Mitchum et al. 1977; Fiedler and Faleide 1996; Kuvaas and Kristoffersen 1996; Nygard et al. 2005). Transparent or weakly reflective intervals may have resulted from subsequent hemipelagic input and more distal turbidites originating from multiple smaller mass wasting events (e.g., Larter and Cunningham 1993). The input of debris appears to have increased after the deposition of subunit M2b. Normal faults flanking respectively. The dark blue line marks the acoustic basement (dotted line marks area where interpretation is less clear). b Section of profile $\mathrm{H} 0531$ at the Alpha Ridge where the seabed and the stratigraphic continuity is disrupted (for location see Fig. 2b). Several normal faults offset acoustic basement and the overlying sediments up to different levels in the sediment section

basement highs on the Mendeleev Ridge all terminate below Unit M1 i.e. high in subunit M2b or within subunit M2a (Figs. 3). Stratigraphic offsets in the sediment succession which are less than the corresponding offsets in the acoustic basement levels suggest both faulting and reactivation of older basement faults. Tectonic activity may have triggered the mass wasting, and the relative abundance of debris in subunit M2a in grabens suggests a tectonic episode at the time of deposition of this subunit. The incised unconformity surface between subunits $\mathrm{M} 2 \mathrm{a}$ and $\mathrm{M} 2 \mathrm{~b}$ observed along the northern slope of the Mendeleev Ridge (Fig. 8) may also relate to mass wasting triggered during this interval.

The predominance of smooth truncations of intact layering and no observations of remanent slide scar head walls 
Fig. 12 Two sections of profile H0533 over the outer margin of the Alpha Ridge (for location see Fig. 2b, 10). Notice that this line is not straight (see Fig. 2b). The green line shows the $\mathrm{AU}$ unconformity, which divides the sediment section at the A1/A2 boundary and truncates layers in Unit A2. The turquoise line marks the top of subunit A2a. The red line marks the top of subunit $\mathrm{A} 2 \mathrm{~b}$, and the yellow line the top of subunit A2c. ARB1, ARB2 and ARB3 mark the Alpha Ridge reflection band 1 , 2,3 , respectively. The dark blue dotted line marks the acoustic basement. Heavy ice encountered during acquisition of this line reduced data quality
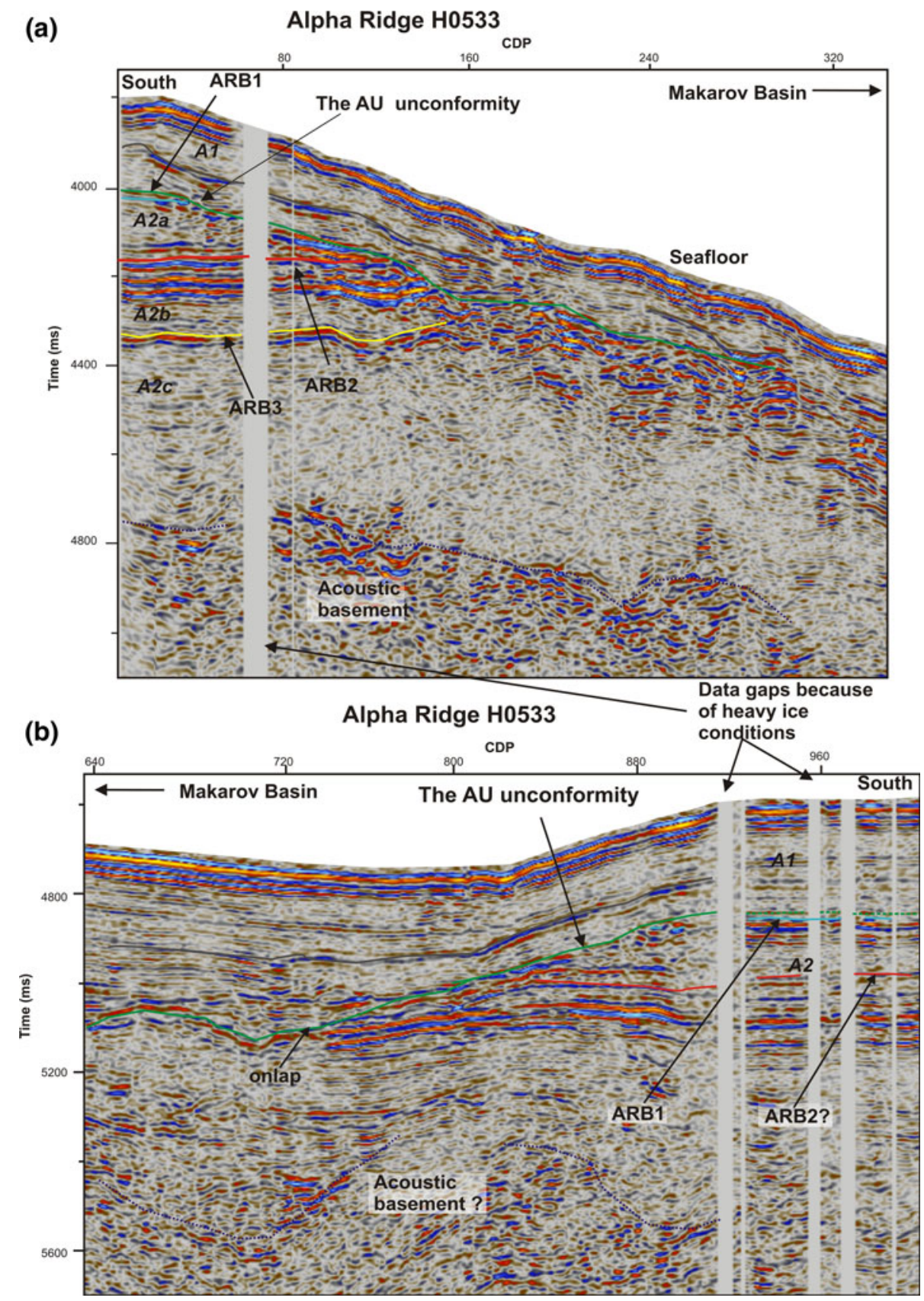

at the perimeter of basement highs (the MU unconformity) suggest that temporal and spatially limited erosion/ non-deposition associated with bottom currents have been important. Gradients in geostrophic, contour-following bottom currents attenuate sediment deposition or erode at the perimeter of a ridge crest and redistribute sediments into contourite drifts (Faugères et al. 1999; Stow et al. 2002). However, the volumes of redistributed sediment would be relatively small in this case. Indications of current activity in the Amerasia Basin is seen from the convex-up sediment body in a graben on the Lomonosov Ridge close to Makarov Basin (Fig. 8 of Jokat (2005), shot point 1600-1400) and possible current erosion on the north slope of the Alpha Ridge (Jokat 2003). Onlap and slight convex up patterns in the upper part of subunit M2a may also represent contourite deposits (Fig 6b, 7). Sediment drift deposits interbedded with mass waste products are difficult to recognize (Faugères et al. 1999; Stow et al. 2002). We suggest that the combined effect of a tectonic episode and bottom current activity both contributed to slope instability and removal of sediments from the upper slopes of basement highs on the Mendeleev Ridge. Similarities in the signature and stratigraphic level of the main AU unconformity at the northwestern Alpha Ridge suggest 
a similar and coeval process including the north western Alpha Ridge.

The reflection bands and their implications for the depositional environment

Unit M2 on the Mendeleev Ridge and Unit A2 on the northwestern Alpha Ridge are interpreted as hemipelagic deposits, and both include several large amplitude, multicycle reflections. Acoustic impedance contrasts within hemipelagic sediments are primarily generated from saturated bulk density contrasts due to variations in the clay content of the sediment. The biogenic carbonate and siliceous components show relatively small velocity contrasts (Mayer 1980; Bayer and Ott 1983). Where multiple thin layers are present, acoustic tuning effects may also be an important cause of strong reflections. Silica-rich sediments are abundant in the Paleogene and older sediments recovered in short cores from Alpha Ridge (Mudie et al. 1986), and strong reflections can also be produced by diagenetic fronts such as opal-A to opal-CT transition (Hesse 1990; Guerin and Goldberg 1996). The acoustic response is a bottom simulating reflection of moderate to high amplitude and positive polarity (Hein et al. 1978; Davies and Cartwright 2002) that may cross-cut depositional surfaces (Davies and Cartwright 2002; Meadows and Davies 2007).

The top of the lower double-cycle reflection bands (MRB2 and ARB3) on the Mendeleev and northwestern Alpha Ridges appears to be a positive amplitude reflection with a seismic signature similar to the planar diagenetic front described by Davies and Cartwright (2002) and Meadows and Davies (2007). The lower reflection bands (MRB2 and ARB3) have constant amplitude, show no cross-cutting relationships, and MR2B is present in grabens where it is much deeper buried. At this point we are unable to discriminate between alternatives where the lower reflection bands may represent a change from bio-siliceous sediment to clay dominated lithology or represent a diagenetic front within a silica-rich interval.

\section{Basement topography and faulting}

The difference in sediment thickness of the lowermost interval M2c between the grabens and surrounding highs on the Mendeleev Ridge suggests ridge relief was in part established prior to deposition of this lowermost unit. Several basement faults predate sediment deposition or have larger basement level offsets than offsets higher in the sediment cover (Fig. 3). Local syn-depositional fault growth is documented by local wedge geometries in subunit M2c and basal sediments rotated with a large fault block also indicate basement uplift early in this interval
(Fig. 9b). Topographic relief was further enhanced at the time of deposition of sub-units M2b and M2a although there is no evidence for growth wedges suggesting that the extensional tectonic movements were episodic. The area along the north eastern slope of Mendeleev Ridge characterized by a chaotic and transparent acoustic pattern extending to the top of subunit M2b (Fig. 9a) and disturbing the sediment continuity around them, may represent an intrusive event contemporaneous with the tectonic episode which destabilized sediments on the slopes of basement highs and generated the MU discontinuity. Alternatively the diffuse reflections may be due to gas blanking.

The data coverage of the Alpha Ridge is limited, but offsets in basement levels seem to be pre-depositional in areas with undisturbed acoustic stratification (Fig. 11a). However, faults are abundant where the stratigraphy is disrupted (Fig. 11b), but the age of this disturbance can not be constrained and may be recent (Kristoffersen et al. 2009).

Stratigraphic correlation between the Mendeleev, northwestern Alpha Ridges and the Lomonosov Ridge

\section{Mendeleev and northwestern Alpha Ridges}

The upper draping Unit M1 on Mendeleev Ridge and Unit A1 on northwestern Alpha Ridge are considered to be time equivalent as they have similar thickness above their respective unconformities (Fig. 13). The undisturbed sediment cover over basement highs on Mendeleev Ridge (Unit M2) and northwestern Alpha Ridge (Unit A2) is characterized by multiple bands of strong reflections (Fig. 13). A thick upper band on Mendeleev Ridge, MRB1, is observed at depths between $\sim 0.28-0.45 \mathrm{~s}$. Two reflection bands are present in this depth range on the northwestern Alpha Ridge; an upper band, ARB1 ( $0.25 \mathrm{~s}$ below seafloor), and a second thicker band, ARB2, at $0.35 \mathrm{~s}$ subbottom depth. The reflection band ARB2 is also observed at $0.35 \mathrm{~s}$ on other seismic lines from northern and western part of Alpha Ridge (Fig. 3 of Jokat 2003). A direct correlation of reflection bands ARB1 with MRB1 is less likely as their seismic signature differs (Fig. 13) and would imply relatively higher sedimentation rates on northwestern Alpha Ridge more distant from any continental margin (Fig. 1). The deeper reflection band ARB2 has approximately the same sub-bottom depth and signature as MRB1 on Mendeleev Ridge and a correlation is more likely (Fig. 13). The deeper reflection bands MRB2 and ARB3, respectively have similar polarity, are both double cycle, and are positioned at approximately corresponding depths which suggest a correlation (Fig. 13). 
Fig. 13 Acoustic stratigraphic correlation between the Mendeleev and northwestern Alpha Ridges

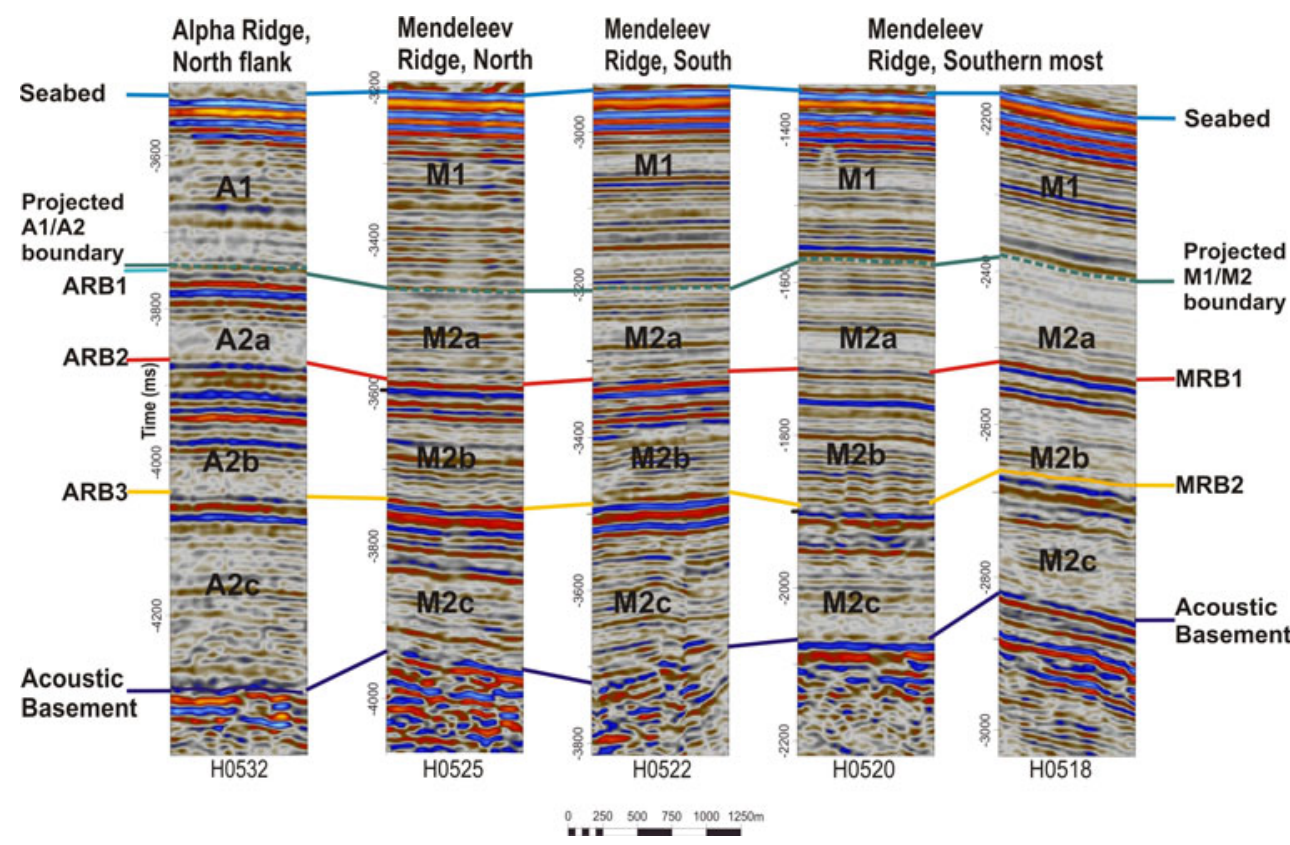

Seismic stratigraphy and core seismic integration at the ACEX drill site, central Lomonosov Ridge

The ACEX core on the central Lomonosov Ridge provides the only key stratigraphic tie point in the central Arctic Ocean. A seismic image of the central flat topped area of the Lomonosov Ridge (from $87^{\circ} 30^{\prime}-88^{\circ} \mathrm{N}$ ) shows a $\sim 0.5 \mathrm{~s}$ uniformly thick sediment cover, tapered at both flanks of the ridge, and resting unconformably on the dipping beds of a prograding wedge facing the Makarov Basin (unconformity LR-3 by Jokat et al. (1992); Jokat (2005)) (Figs. 14, 15, upper panel). Within the Cenozoic marine succession (Moran et al. 2006) above LR-3 is another well defined angular unconformity at $0.2 \mathrm{~s}$ below the sea-bed, but restricted to the flank of Lomonosov Ridge, about $15 \mathrm{~km}$ north of the ACEX drill sites (Fig. 15).
This discontinuity, LU, may be traced upslope the Eurasia Basin flank to an associated conformable stratigraphic surface and continued cross Lomonosov Ridge where it matches a corresponding disconformity on the Makarov Basin flank (Fig. 14). The along-ridge extent of this geometrical relationship is unknown.

This unconformity divides the Paleocene-Recent succession imaged on line AWI 91090 into an upper draping acoustic Unit L1 (0.20-0.23 s thick), which overlies Unit L2, characterized by two sets of reflection bands (Fig. 15). The nomenclature of Jokat et al. (1995a) based on reflection character and velocities are shown in Fig. 15 (lower panel, left) for comparison. The acoustic stratigraphic position of the LU unconformity is directly tied to the discordant geometry on the adjacent slope and its correlative surface falls above the position of the acoustic
Fig. 14 Line drawings of the seafloor, unconformities and key reflections in part of seismic profile AWI91090 across the Lomonosov Ridge (for location see Fig. 1)

\section{Lomonosov Ridge}

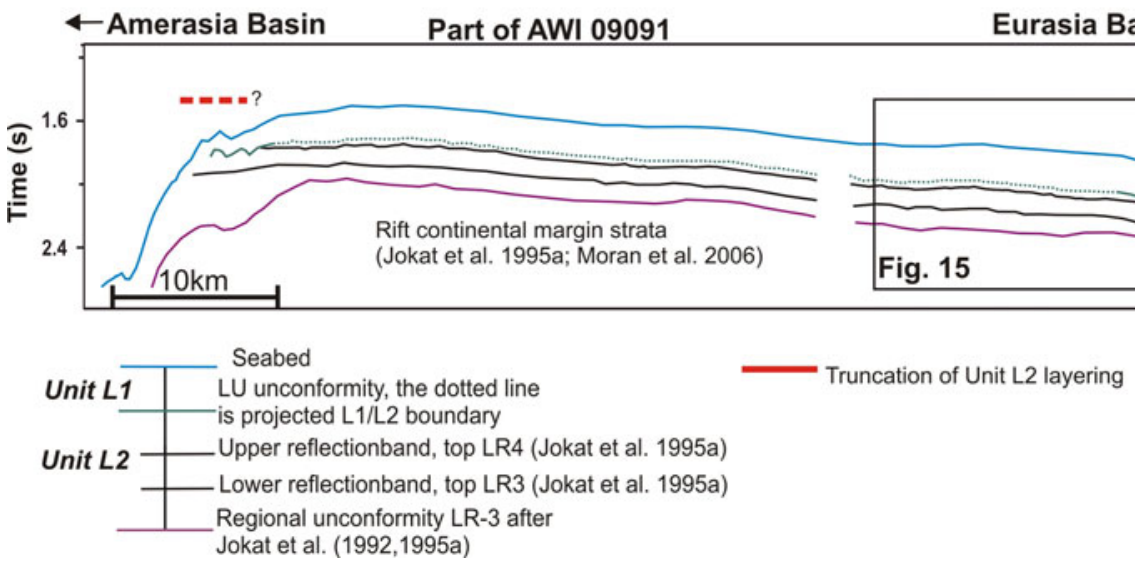


Fig. 15 Section of line AWI91090 from the central part of the Lomonosov Ridge with the key features of this and earlier work (for location see Fig. 1, 14). The depth of the composite ACEX core is marked by black line at the location of drill site M004. The green line shows the LU unconformity that divides the sediment section into units L1 and L2. Note that the upper unconformity (green line) and its projected surface (dotted green line) can be traced to a level above the upper reflection band and the top of LR4 of Jokat et al. (1995a). Also note the truncation of intact layering and the small collapse faults at the perimeter of the ridge

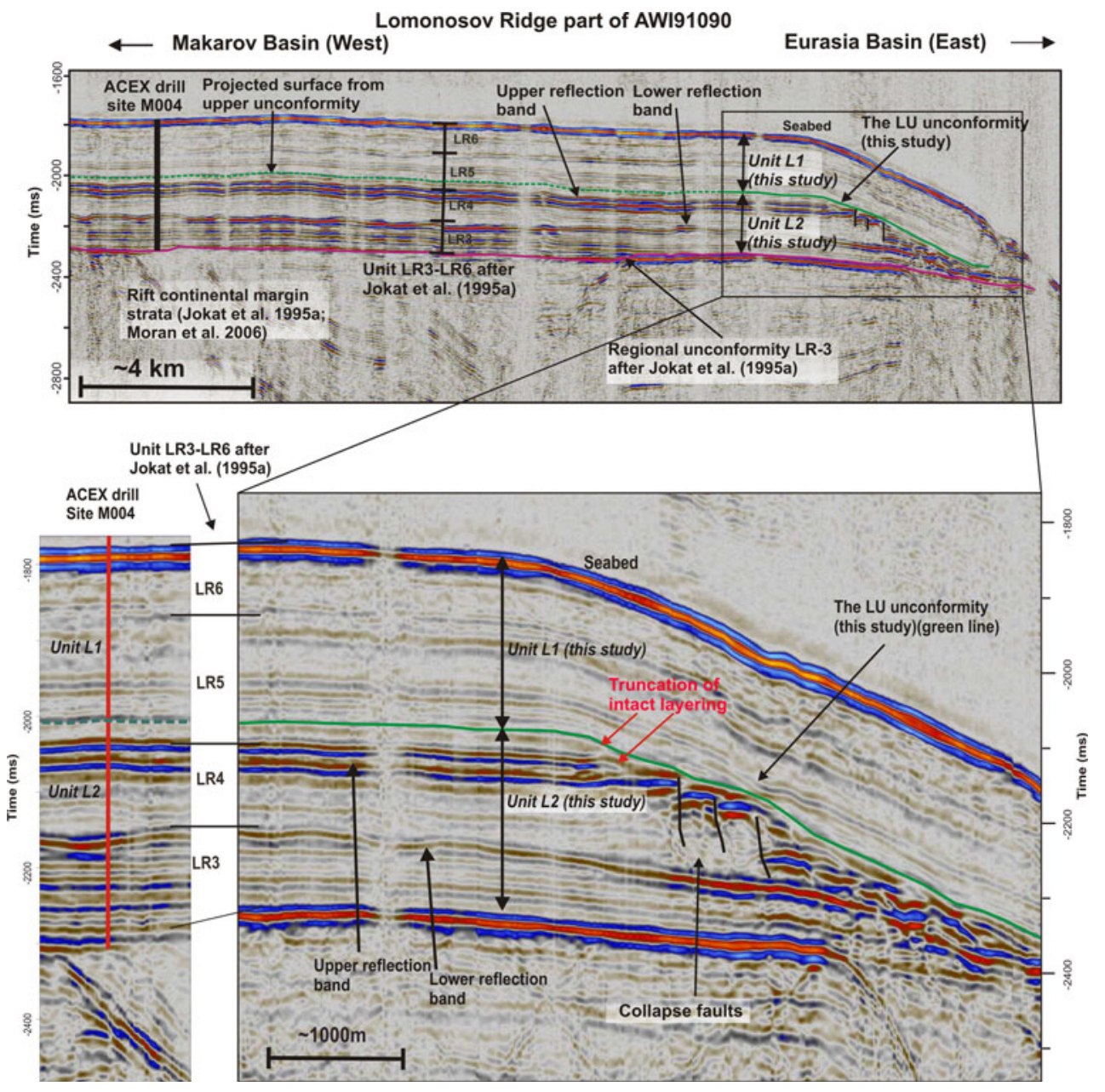

response of the hiatus (Fig. 16) as proposed by matching acoustic stratigraphy with core data using synthetic seismogram (Jakobsson et al. 2007; Backman et al. 2008).

The LU unconformity appears as a smooth surface in its upper part, passing down-slope into a series of progressively disintegrating fault blocks (Fig. 15, lower panel right) where intact strata have become unstable and partly removed by mass wasting. No relict head walls are apparent and the remaining sediment scar has been smoothed. The LU unconformity on Lomonosov Ridge appears restricted to the flank as on Mendeleev and Alpha Ridges and may have been generated from sediment instability induced by slope undercutting from bottom currents an/or tectonic movements. The presence of sediment drift deposits farther down the Eurasia flank along the same AWI09091 seismic line (Fig. 2 in Jokat et al. 1992) support bottom current activity in this interval.

The acoustic stratigraphic level associated with the LU unconformity projects to the approximate position of the subunit 1/4-1/3 boundary ( $\sim 14.5 \mathrm{Ma}$ ) at the ACEX drill site (Fig. 16) using results of the core-seismic integration of Backman et al. (2008). Alternatively, a match between the seismostratigraphic position of the LU unconformity and the core hiatus would be more appropriate. Below the hiatus, these authors correlate the boundary between subunit 1/6 and Unit 2 to the lower part of the double-cycle reflection band (Fig. 16), and the boundary between Unit 2 and -3 to the top of the second reflection band (Jakobsson et al. 2007; Backman et al. 2008).

\section{An inter-ridge stratigraphic correlation}

Within the limits of available data, the upper $0.5 \mathrm{~s}$ of the sediment cover on the Mendeleev and northwestern Alpha Ridges as well as the central part of Lomonosov Ridge in the Arctic Ocean appears to share common attributes such as;

(1) an upper $\sim 0.20-0.25 \mathrm{~s}$ thick draping unit that is conformable with underlying strata over flat or gently sloping ridge highs, but rests on truncated layers on the adjacent upper slopes (Figs. 3, 10, 14), and

(2) sediments below the upper drape also have the character of hemi-pelagic deposits and include several high amplitude, multi-cycle reflection bands 


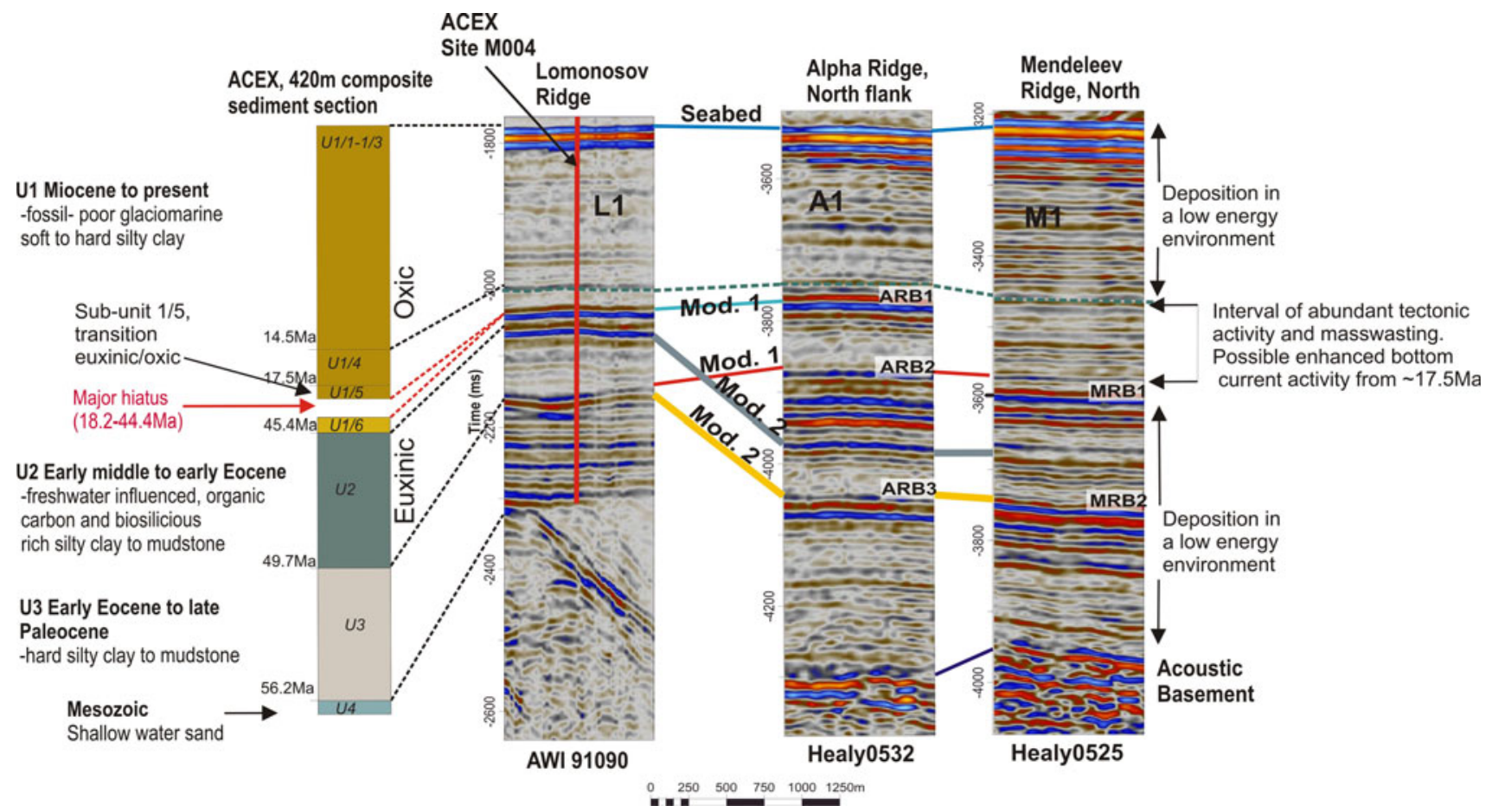

Fig. 16 Acoustic stratigraphic correlation between Lomonosov, Mendeleev, and Alpha Ridges. Notice the two possible alternatives for inter-ridge correlation between the Lomonosov Ridge and the Alpha and Mendeleev Ridges. Core description is from Moran et al.
(2006) and Backman et al. (2008), and tie between seismic and core from core- seismic integration of Jakobsson et al. (2007) and Backman et al. (2008)

Model 1: A direct correlation between reflection bands (Fig. 16, Mod. 1) will imply reduced deposition, non deposition or erosion on the Mendeleev Ridge and northwestern part of Alpha Ridge as documented for the central part of the Lomonosov Ridge (Moran et al. 2006; Sangiorgi et al. 2008).

Model 2: Assumes continuous deposition on the undisturbed crestal areas of the Mendeleev and Alpha Ridges during the hiatus on the Lomonosov Ridge at the ACEX drill site. The lower Unit L2 on the Lomonosov Ridge is capped by a middle Eocene early Miocene stratigraphic break and the initial vertical extent of the upper reflection band is unknown. We therefore correlate the base of the upper reflection band on the Lomonosov Ridge with the bases of bands ARB2 and MRB1 on the Alpha and Mendeleev Ridges, respectively (Fig. 16, Mod 2.). Deeper in the succession, the top of the lower reflection band at the Lomonosov Ridge has been correlated with bands ARB3 and MRB2.

The second alternative is favoured because; (1) the ridge flank unconformities have associated correlative surfaces over the ridge highs with no related impedance contrasts, and (2) a condensed or truncated section on the highs of Mendeleev Ridge is less likely as subunit M2b has approximately the same thickness and signature within the grabens as below the highs. 


\section{Discussion}

Origin of the MU, LU and AU unconformity surfaces at the Mendeleev Ridge, northwestern part of Alpha Ridge and Lomonosov Ridge

The disconformity topographically restricted to the upper and middle slopes of Mendeleev Ridge and northwestern part of Alpha Ridge and Lomonosov Ridge is suggested to originate from mass wasting induced by tectonic events and the action of enhanced bottom currents. Debris from mass wasting is particularly abundant in adjacent grabens within subunit M2a right below the discordance, while evidence of sediment drifts in the same stratigraphic position is more subtle. Smooth truncations of intact layering dominate and no evidence of relict head walls left from displaced sediments suggests bottom current erosion. Offsets in acoustic basement and the sediment cover appear to vanish within or below subunit M2a and the relative abundance of debris flows within grabens suggest slope destabilization culminated during deposition of subunit M2a. A chaotic reflection pattern along the eastern slope of Mendeleev Ridge (Fig. 9a) could be interpreted as local igneous activity within this period. The phase of tectonic activity is estimated to early Miocene ( 22-14 Ma), assuming continuous deposition at an average Neogene sedimentation rate of $1.2 \mathrm{~cm} / \mathrm{ka}$ (Backman and Moran 2009) and average compressional velocity of $1.6 \mathrm{~km} / \mathrm{s}$.

The Mendeleev and Alpha Ridges are distant from known Oligocene/early Miocene plate boundaries or zones of tectonic activity such as (a) the Gakkel spreading centre and its continuation as an extensional regime on the Laptev Sea continental margin (Sekretov 2001 Drachev et al. 1998), (b) the proposed crustal shortening north of Greenland (Brozena et al. 2003) and (c) the main phase of folding and thrusting during the Eurekan orogeny (De Paor et al. 1989); the two last events being no younger than Oligocene. Possible trajectories of transmitted far-field effects from tectonic events are difficult to document as there is no reported significant sediment deformation in the Eurasia Basin (Jokat et al. 1995b; Jokat and Micksch 2004), in the Makarov Basin (Sorokin et al. 1999), or in the central Canada Basin (Grantz et al. 2009). The central part of Lomonosov Ridge started subsiding in the early Miocene, 35 million years after separation from the Barentsand Kara Sea margin (Sangiorgi et al. 2008), but how this delay relates to regional plate stresses remains highly speculative (O'Reagan et al. 2008). We feel there is insufficient data at present to establish a direct link between the observed early Miocene episode of extensional tectonics on Mendeleev Ridge and regional tectonic events. Another possibility is a regionally restricted activity in the central Arctic Ocean akind to documented intra-plate local events of faulting and doming occurring from Late Eocene to Late Miocene along the northwest European Atlantic continental margin (Doré et al. 1999).

Bottom current erosion has most likely contributed to generate smooth unconformable surfaces between units M1 and M2 on Mendeleev Ridge and A1 and A2 on northwestern Alpha Ridge, Lomonosov Ridge, respectively as well as destabilized the slopes. However, the internal circulation below the wind-driven surface layer $(0-200 \mathrm{~m})$ in a closed ocean basin is primarily induced through diapychnal flow from lateral differences in vertical mixing. This process would have been suppressed in the stably stratified water masses (Stein et al. 2006; Stickley et al. 2008) of a euxinic (Sluijs et al. 2006; Stein et al. 2006) preearly Miocene Arctic Ocean. The Late Cretaceous- early Cenozoic bottom currents in the Amerasia Basin were probably slow while only shallow seaways existed as there is no evidence in the seismic reflection data from Alpha and Mendeleev Ridges of extensive bottom current erosion within the lower units A2 and M2, respectively. Also, the uppermost Paleocene to middle Eocene sequence on Lomonosov Ridge suggests sluggish deep water circulation (Brinkhuis et al. 2006).

The change represented by early Miocene opening of the Fram Strait gateway (Engen et al. 2008) provided a teleconnection to the North Atlantic thermohaline circulation, primed Arctic Ocean circulation and oxygenated the basins (Jakobsson et al. 2007). Opening of the Fram Strait and exchange of deepwater between the Arctic and Atlantic Oceans is also suggested to relate to an Early Neogene massive increase in contourite drift formation in the Northern Atlantic and Norwegian-Greenland Sea (Laberg et al. 2005).

Enhanced current circulation may have started with the transition to an oxygenated Arctic Ocean at about $17.5 \mathrm{Ma}$ (Jakobsson et al. 2007) and lasted until the onset of deposition of the undisturbed upper drape (Unit L1) correlated to subunit $1 / 4-1 / 3$ boundary in the ACEX core ( $\sim 14.5 \mathrm{Ma})$. The omnipresent uniformity of the upper drape (units M1, A1 and L1) suggest relatively slow post middle Miocene bottom current circulation much like today (Hunkins et al. 1969; Woodgate et al. 2001; Isachsen et al. 2003; Woodgate et al. 2007).

Implications of an inter-ridge stratigraphic correlation

The implications of Model 2 (Fig. 16) are continuous deposition over the basement highs while the unconformities between units, MU on Mendeleev Ridge, AU on northwestern Alpha Ridge and LU on central Lomonosov Ridge, formed along their respective upper flanks. Sediments of subunit M2b on the Mendeleev Ridge and subunit $\mathrm{A} 2 \mathrm{~b}$ on northwestern Alpha Ridge may be equivalent to the 
Eocene biosiliceous clays and mudstones (ACEX Unit 2) deposited from 49.7 Ma and onwards. Biosiliceous ooze of this age is recovered on Alpha Ridge in core 422 (Bukry 1984; Mudie et al. 1986). A biosiliceous-rich unit would be poorly consolidated and susceptible to slope failure as observed in more recent events on Lomonosov Ridge (Kristoffersen et al. 2007). Model 2 also implies that the top of reflection bands MRB2 and AR3B are equivalent to the top of early Eocene and older silty clays and mudstones (49.7 Ma) (Fig. 16). However, the latter correlation is of questionable value as the late Paleocene- early Eocene depositional environment on the shallow Lomonosov Ridge most likely differed from the older and deeper Mendeleev and Alpha Ridges. Also the thermal and subsidence history of Lomonosov Ridge are different from Mendeleev and Alpha Ridges and leave open any associations of the lower reflection bands on Mendeleev and Alpha Ridges with Opal A to Opal CT transition as suggested for Unit $2 / 3$ transition in the ACEX core from Lomonosov Ridge (O'Reagan et al. 2009). The age of the oldest sediments above acoustic basement on the Mendeleev and northwestern Alpha Ridges is estimated to be $\sim 70-75 \mathrm{Ma}$ from the thickness $(\sim 0.20-0.25 \mathrm{~s})$ below the top of MRB2 and ARB3 (Fig. 13) assuming a seismic interval velocity of $2.0 \mathrm{~km} / \mathrm{s}$ and a hemipelagic sedimentation rate of $\sim 1 \mathrm{~cm} / \mathrm{ka}$.

\section{Summary and conclusions}

The top of Mendeleev Ridge and northwestern part of Alpha Ridge are draped by a 0.6-0.8 s thick succession of hemipelagic sediments above acoustic basement. The lack of systematic variation in thickness and rather similar acoustic reflection patterns argue for broadly similar depositional environments on the two ridges.

An angular discordance confined to the middle and upper slopes of the bathymetric highs is well documented on the Mendeleev Ridge (the MU unconformity), and also observed on the investigated northwestern part of Alpha Ridge (the AU unconformity). This disconformity divides the section into; an upper, uniform and undisturbed drape, and a lower unit characterized by internal strong multicycle reflection bands. Debris from mass wasting is abundant in intra-ridge grabens on Mendeleev Ridge below the stratigraphic level corresponding to the MU unconformity. The angular discordance is suggested to result from the combined effect of sediment instability and mass wasting triggered by tectonic activity and smoothed by enhanced erosive bottom currents acting at the same time. Opening of the Fram Strait gateway and increased efficiency of an oceanographic circulation may explain enhanced bottom currents within the estimated $\sim 22-14$ Ma time frame for deposition of subunit M2a on Mendeleev Ridge, but any direct link between normal faulting on the Mendeleev and Alpha Ridges and regional plate stresses remains elusive.

The upper $0.5 \mathrm{~s}$ of the sediment cover on the Mendeleev and northwestern Alpha Ridges share common attributes with the central part of the Lomonosov Ridge. We make a correlation between the MU unconformity on the Mendeleev Ridge and the AU unconformity on Alpha Ridge to an unconformity on the flanks of central Lomonosov Ridge (the LU unconformity) stratigraphically above the hiatus at the ACEX drill site (18.2-44.4 Ma). Calibration to the ACEX results suggests a period of increased bottom current activity in the Arctic Ocean (Fig. 16) starting at the transition from euxinic to oxic conditions at the ACEX site (17.5 Ma) and becoming less effective at the beginning of deposition of Unit M1 (14.5 Ma). The $0.2 \mathrm{~s}$ thick drape (units L1, A1 and M1) above the flank disconformity on all three ridges is represented by hemipelagic clays of glaciomarine origin deposited in a low energy regime similar to the present day conditions. Sediment deposition on basement highs on all ridges was most likely continuous throughout the phase of mass wasting and bottom current erosion along their respective flanks.

The lower unit on Mendeleev (M2), northwestern part of Alpha (A2) and Lomonosov (L2) Ridges is dominated by internal strong multi-cycle acoustic reflection bands. Two alternative inter-ridge correlations follows from the hiatus recorded at the ACEX drill site. The preferred alternative implies continuous deposition on the highs of the Mendeleev and Alpha Ridges while non-deposition or erosion occurred on the crest of central Lomonosov Ridge. The correlation implies that the acoustic reflection bands on the Mendeleev and northwestern Alpha and ridges most likely relates to changes from clay rich deposits to biosiliceous sediment and back to clay dominated lithology again.

Acknowledgement We thank captain D. Oliver and the crew of the USCG icebreaker Healy. Healy cruise 0503 by NSF award \# 0449898 to Geophysical Institute, University of Alaska, Fairbanks, and \# 0447440 to Texas A\&M University, College Station, Texas. MCS acquisition and Norwegian participation in Healy cruise 0503 was funded by the Norwegian Petroleum Directorate. We are grateful to the Healy (2005) Seismic Team (Paul Henkart, Scripps Institution of Oceanography, USA; Tore Arthun, Hans Berge and Erik Grindvoll, University of Bergen, Norway; Hedda Breien, University of Oslo, Norway; Dayton Dove, University of Alaska, Fairbanks, USA; Nina Ivanova, University of Uppsala, Sweden; Fredrik Ludvigsen, Thor Heyerdahl High School, Larvik, Norway; and Karina Monsen, Alta High School, Alta Norway) for their effort and companionship during the cruise. We also thank two anonymous reviewers for their efforts and constructive comments.

Open Access This article is distributed under the terms of the Creative Commons Attribution Noncommercial License which permits any noncommercial use, distribution, and reproduction in any medium, provided the original author(s) and source are credited. 


\section{References}

Aagaard K, Carmack EC (1994) The Arctic Ocean and Climate: A Perspective. In: Johannessen, OM, Muench, RD, Overland JE (eds) The Polar Oceans and Their Role in Shaping the Global Environment, Geophys Monogr Ser, vol 85. AGU, Washington, DC, pp 5-20

Aagaard K, Coachman LK, Carmack E (1981) On the Halocline of the Arctic Ocean. Deep-Sea Res 28:529-545

Aagaard K, Swift JH, Carmack EC (1985) Thermohaline circulation in the Arctic Mediterranean seas. J Geophys Res 90(C3): 4833-4846

Backman J, Moran K (2009) Expanding the Cenozoic paleoceanographic record in the central Arctic Ocean: IODP Expedition 302 Synthesis. Cent Eur J geosc. 1(2). doi 10.2478/v10085-0090015-6

Backman J, Jakobsson M, Frank M, Sangiorgi F, Brinkhuis H, Stickley C, O'Regan M, Lovlie R, Palike H, Spofforth D, Gattacecca J, Moran K, King J, Heil C (2008) Age model and core-seismic integration for the Cenozoic Arctic Coring Expedition sediments from the Lomonosov Ridge. Paleoceanography 23, PA1S03. doi:10.1029/2007PA00147

Baraboshkin EY, Alekseev AS, Kopaevich LF (2003) Cretaceous palaeogeography of the North-Eastern Peri-Tethys. Palaeogeogr Palaeoclimatol Palaeoecol 196:177-208

Bayer U, Ott R (1983) Correlation of acoustic stratigraphy with cored lithology by means of physical property data for deep-sea drilling project site-511, site-513, and site-514, leg-71: initial reports of the deep sea drilling project 71:1133-1137. doi: 10.2973/dsdp.proc.71.146.1983

Brinkhuis H, Schouten S, Collinson ME, Sluijs A, Damste JSS, Dickens GR, Huber M, Cronin TM, Onodera J, Takahashi K, Bujak JP, Stein R, Van der Burgh J, Eldrett JS, Harding IC, Lotter AF, Sangiorgi F, Cittert HVV, de Leeuw JW, Matthiessen J, Backman J, Moran K (2006) Episodic fresh surface waters in the Eocene Arctic Ocean. Nature 441:606-609

Brozena JM, Childers VA, Lawver LA, Gahagan LM, Forsberg R, Faleide JI, Eldholm O (2003) New aerogeophysical study of the Eurasia Basin and Lomonosov Ridge: implications for basin development. Geology 31:825-828

Bukry D (1984) Paleogene paleoceanography of the Arctic Ocean is constrained by the middle or late Eocene age of USGS Core Fl422: evidence from silicoflagellates. Geology 12:199-201

Davies RJ, Cartwright J (2002) A fossilized Opal A to Opal C/T transformation on the northeast Atlantic margin: support for a significantly elevated Palaeogeothermal gradient during the Neogene? Basin Res 14:467-486

De Paor DG, Bradley DC, Eisenstadt G, Philips SM (1989) The Arctic Eurekan orogen: a most unusual fold-and-thrust belt. Geol Soc Am Bull 101:952-967

Dell'Agnese DJ, Clark DL (1994) Siliceous microfossils from the warm Late Cretaceous and early Cenozoic Arctic Ocean. J Paleontol 68:31-47

Doré AG, Lundin ER, Jensen LN Birkeland Ø, Eliassen PE, Fichler C (1999) Principal tectonic events in the evolution of the northwest European Atlantic margin. In: Fleet AJ, Boldy SAR (eds) Petroleum geology of Northwest Europe Proceedings 5th Conference, Geol Soc, vol 1, pp 41-63

Drachev S, Savostion L, Groshev VG, Bruni IE (1998) Structure and geology of the continental shelf of the Laptev Sea, Eastern Russian Arctic. Tectonophys 298:357-393

Eldholm O, Karasik AM, Reksnes PA (1990) The North American plate boundary. In: Grantz A, Johnson GL, Sweeney JF (eds) The Arctic Ocean region, part of The Geology of North America, vol L. Geol Soc Am, Boulder, CO, pp 171-184
Embry A (1990) Geological and geophysical evidence in support of the hypothesis of anticlockwise rotation of Northern Alaska. Mar Geol 93:317-329

Engen Ø, Faleide JI, Dyreng TK (2008) Opening of the Fram Strait gateway-a review of plate tectonic constraints. Tectonophysics 450:51-69. doi:10.1016/j.tecto.2008.01.002

Engen $\varnothing$, Gjengedal JA, Faleide JI, Kristoffersen Y, Eldholm O (2009) Seismic stratigraphy and sediment thickness of the Nansen Basin, Arctic Ocean. Geophys J Int 176:3:805-821. doi: 10.1111/j.1365-246X.2008.04028.x

Esmerode EV, Lykke-Andersen H, Surlyk F (2008) Interaction between bottom currents and slope failure in the late cretaceous of the Southern Danish Central Graben, North Sea. J Geol Soc 165:55-72. doi:10.1144/0016-76492006-138

Faugères JC, Stow DAV, Imbert P, Viana A (1999) Seismic features diagnostic of contourite drifts. Mar Geol 162:1-38

Fiedler A, Faleide JI (1996) Cenozoic sedimentation along the Southwestern Barents Sea margin in relation to uplift and erosion of the shelf. Glob and Planet Change 12:75-93

Firth JV, Clark DL (1998) An early Maastrichtian organic-walled phytoplankton cyst assemblage from an organic-rich black mud in core Fl-533, Alpha Ridge; evidence for upwelling conditions in the Cretaceous Arctic Ocean. Mar Micropaleontol 34:1-27

Forsyth DA, Asudeh I, Green AG, Jackson HR (1986) Crustal structure of the northern Alpha Ridge beneath the Arctic Ocean. Nature 322:349-352

Gauer P, Kvalstad TJ, Forsberg CF, Bryn P, Berg K (2005) The last phase of the Storegga Slide; simulation of retrogressive slide dynamics and comparison with slide-scar morphology (in Ormen Lange; an integrated study for the safe development of a deepwater gas field within the Storegga Slide Complex, NE Atlantic continental margin). Mar Pet Geol 22(1-2):171-178

Gjengedal JA (2004) Ei geofysisk undersøking av Nansenbassenget og Yermakplatået. Cand. Scient thesis, University of Bergen, Norway, 160pp

Gleason JD, Thomas DJ, Moore TC, Blum JD, Owen RM, Haley BA (2009) Early to middle eocene history of the Arctic Ocean from $\mathrm{Nd}-\mathrm{Sr}$ isotopes in fossil fish debris, Lomonosov Ridge paleoceanography, 24: PA2215.doi:10.1029/2008PA001685

Glebovsky V, Likhachev A, Kristoffersen Y, Engen $\emptyset$, Faleide JI, Brekke H (2006) Sedimentary thickness estimations from magnetic data in the Nansen Basin. In: Scott RA., Thurston DK (eds) Proceedings of the fourth International Confrence on Arctic Margins, OCS Study MMS 2006-003, pp157-164

Grantz A, May SD, Taylor PT, Lawver LA (1990) Canada Basin. In: Grantz A, Johnson GL, Sweeney JF (eds) The Geology of North America, vol L, The Arctic Ocean region. Geol Soc Am, Boulder, Colorado, pp 379-402

Grantz A, Clark DL, Phillips RL, Srivastava SP, Blome CD, Gray LB, Haga H, Mamet BL, McIntyre DJ, Mcneil DH, Mickey MB, Mullen MW, Murchey BI, Ross CA, Stevens CH, Silberling NJ, Wall JH, Willard DA (1998) Phanerozoic stratigraphy of Northwind Ridge, magnetic anomalies in the Canada basin, and the geometry and timing of rifting in the Amerasia basin, Arctic Ocean: Geol Soc Am Bull 110:801-820

Grantz A, Pease VL, Willard DA, Phillips RL, Clark DL (2001) Bedrock cores from $89^{\circ}$ North: implications for the geologic framework and Neogene paleoceanography of Lomonosov Ridge and a tie to the Barents shelf. Geol Soc Am Bull 113: 1272-1281

Grantz A, Hart PE, Childers VA (2009) Geology and tectonic development of the Amerasia and Canadian Basin, Arctic Ocean. In: Spencer AM, Gautier D, Stoupakova A, Embey A, Sørensen K (eds) Arctic Petroleum Geology, Geol. Society of London (in press)

Guerin G, Goldberg D (1996) Acoustic and elastic properties of calcareous sediments across a siliceous diagenetic front on 
the eastern US continental slope. Geophys Res Letters 23: $2697-2700$

Hein JR, Scholl DW, Barron JA, Jones MG, Miller J (1978) Diagenesis of late Cenozoic diatomaceous deposits and formation of the bottom simulating reflector in the southern Bering sea. Sedimentology 25:155-177

Hesse R (1990) Origin of chert: diagenesis of biogenic siliceous sediments, geoscience Canada reprint series 4. Geological Association of Canada, pp 227-251

Hunkins K, Ewing M, Heezen B, Menzies RJ (1960) Biological and geological observations on the first photographs of the Arctic Ocean deep-sea floor. Limnol Oceanogr 5:154-161

Hunkins K, Thorndik EM, Mathieu G (1969) Nepheloid layers and bottom currents in Arctic Ocean. J Geophys Res 74: 6995-7008

Isachsen PE, LaCasce JH, Mauritzen C, Hakkinen S (2003) Winddriven variability of the large-scale recirculating flow in the Nordic seas and Arctic Ocean. J Phys Oceanogr 33:2534-2550

Jackson HR, Forsyth DA, Johnson GL (1986) Oceanic affinities of the Alpha Ridge Arctic Ocean. Mar Geol 73:237-261

Jakobsson M, Backman J, Rudels B, Nycander J, Frank M, Mayer L, Jokat W, Sangiorgi F, O'Regan M, Brinkhuis H, King J, Moran K (2007) The early Miocene onset of a ventilated circulation regime in the Arctic Ocean. Nature 447:986-990. doi:10.1038/ nature 05924

Jakobsson M, Macnab R, Mayer L, Anderson R, Edwards M, Hatzky J, Schenke HW, Johnson P (2008) An improved bathymetric portrayal of the Arctic Ocean: implications for ocean modeling and geological, geophysical and oceanographic analyses. Geophys Res Lett 35:L07602. doi:10.1029/2008GL033520

Jokat W (2003) Seismic investigations along the western sector of Alpha Ridge, Central Arctic Ocean. Geophys J Int 152:185-201

Jokat W (2005) The sedimentary structure of the Lomonosov Ridge between 88 and $80^{\circ} \mathrm{N}$. Geophys J Int 163:698-726

Jokat W, Micksch U (2004) Sedimentary structure of the Nansen and Amundsen basins, Arctic Ocean. Geophys Res Lett 31:L02603. doi:10.1029/2003GL018352

Jokat W, Uenzelmann-Neben G, Kristoffersen Y, Rasmussen TM (1992) Lomonosov ridge - a double-sided continental-margin. Geology 20:887-890

Jokat W, Weigelt E, Kristoffersen Y, Rasmussen T, Schone T (1995a) New insights into the evolution of the Lomonosov Ridge and the Eurasian Basin. Geophys J Int 122:378-392

Jokat W, Weigelt E, Kristoffersen Y, Rasmussen T, Schöne T (1995b) New geophysical results from the south-western Eurasian Basin (Morris Jesup Rise, Gakkel Ridge, Yermak Plateau) and the Fram Strait. Geophys J Int 123(2):601-610

Jones EP (2001) Circulation in the Arctic Ocean. Polar Res 20: 139-146

Jones EP, Rudels B, Anderson LG (1995) Deep waters of the ArcticOcean-Origins and Circulation. Deep Sea Res. Part I Oceanogr. Res. Pap 42:737-760

Karasik AM (1968) Magnetic anomalies of the Gakkel Ridge and origin of the Eurasian-Subbasin of the Arctic Ocean. In: Geophysical methods of exploration in the Arctic, NIIGA, Leningrad, vol 5, pp 8-19 (translated from Russian)

Kauffman EG, Caldwell WGE (1993) The Western Interior Basin in space and time. In: Caldwell WGE, Kauffman EG (eds) Evolution of the Western Interior basin, Special paper 39. Geol Assoc, Canada, pp 1-30

Kitchell JA, Clark DL (1982) Late Cretaceous-Paleogene paleogeography and paleocirculation; evidence of north polar upwelling. Palaeogeogr Palaeoclimatol Palaeoecol 40:135-165

Kristoffersen Y, Coakley BJ, Hall JK, Edwards M (2007) Mass wasting on the submarine Lomonosov Ridge, central Arctic Ocean. Mar Geol 243:132-142
Kristoffersen Y, Hall JK, Hunkins K, Ardai J, Coakley B, Hopper J, The Healy 2005 Seismic Team (2009) Extensive local seabed disturbance, erosion and mass wasting on Alpha Ridge, Central Arctic Ocean: possible evidence for an extra-terrestrial impact? Norwegian J Geol 88:313-320

Kuvaas B, Kristoffersen Y (1996) Mass movements in glaciomarine sediments on the Barents sea continental slope. Glob and Planet Change 12:287-307

Kvalstad TJ, Andresen L, Forsberg CF, Berg K, Bryn P, Wangen M (2005) The Storegga slide; evaluation of triggering sources and slide mechanics. Mar Petrol Geol 22:245-256

Laberg JS, Stoker MS, Dahlgren KIT, de Haas H, Haflidason H, Hjelstuen BO, Nielsen T, Shannon PM, Vorren TO, van Weering TCE, Ceramicola S (2005) Cenozoic alongslope processes and sedimentation on the NW European Atlantic margin. Mar Petr Geol 22:1069-1088

Larter RD, Cunningham AP (1993) The depositional pattern and distribution of glacial-interglacial sequences on the Antarctic Peninsula Pacific margin. Mar Geol 109:203-219

Lawver LA, Muller RD (1994) Iceland hotspot track. Geology 22:311-314

Lawver LA, Grantz A, Gahagan LM (2002) Plate kinematic evolution of the present Arctic region since the Ordovician. Special PaperGeol Soc Am 360:333-358

Lebedeva-Ivanova NN, Zamansky YY, Langinen AE, Sorokin MY (2006) Seismic profiling across the Mendeleev Ridge at $82^{\circ} \mathrm{N}$ : evidence of continental crust. Geophys J Int 165:527-544

Mayer LA (1980) Deep-sea carbonates; physical property relationships and the origin of high-frequency acoustic reflectors. Mar Geol 38:165-183

Meadows D, Davies RJ (2007) Morphological development of basinscale silica diagenetic fronts revealed with 2D seismic reflection data: offshore Sakhalin, Russian Far East. J Geol Soc 164: 1193-1206

Miller EL, Toro J, Gehrels G, Amato JM, Prokopiev A, Tuchkova MI, Akinin VV, Dumitru TA, Moore T, Cecile MP (2006) New insights into Arctic palaeogeography and tectonics from $\mathrm{U}-\mathrm{Pb}$ detrital zircon geochronology. Tectonics 25 TC3013. doi: 10.1029/2005TC001830,2006

Mitchum RM, Vail PR, Sangree JB (1977) Seismic stratigraphy and global changes of sea level; Part 6, Stratigraphic interpretation of seismic reflection patterns in depositional sequences. Seismic Stratigraphy-Application to Hydrocarbon Exploration, APPG Memoir 26:117-133

Moran K, Backman J, Brinkhuis H, Clemens SC, Cronin T, Dickens GR, Eynaud F, Gattacceca J, Jakobsson M, Jordan RW, Kaminski M, King J, Koc N, Krylov A, Martinez N, Matthiessen J, McInroy D, Moore TC, Onodera J, O'Regan M, Palike H, Rea B, Rio D, Sakamoto T, Smith DC, Stein R, St John K, Suto I, Suzuki N, Takahashi K, Watanabe M, Yamamoto M, Farrell J, Frank M, Kubik P, Jokat W, Kristoffersen Y (2006) The Cenozoic palaeoenvironment of the Arctic Ocean. Nature 441. doi:10.1038/nature04800

Mudie PJ, Stoffyn-Egli P, Van Wagoner NA, Johnson GL, Kaminuma K (1986) Geological constraints for tectonic models of the Alpha Ridge. J Geodyn 6:215-236

Nixon MF, Grozic JLH (2006) A simple model for submarine slope stability analysis with gas hydrates. Norwegian J Geol 86: 309-316

Nygard A, Sejrup HP, Haflidason H, Bryn P (2005) The glacial North Sea Fan, southern Norwegian margin; architecture and evolution from the upper continental slope to the deep-sea basin. Mar Pet Geol 22:71-84

O'Reagan M, Moran K, Backman J, Jakobsson M, Sangiorgi F, Brinkhuis H, Pockalny R, Skelton A, Stickley C, Koc N, Brumsack HJ, Willard D (2008) Mid-Cenozoic tectonic and 
paleoenvironmental setting of the central Arctic Ocean Paleoceanography 23, PA1S20. doi:10.1029/2007PA001559

O'Reagan M, Moran K, Baxter CDP, Cartwright J, Vogt C, Köllings M (2009) Towards ground truthing exploration in the central Arctic Ocean: a Cenozoic compaction history from the Lomonosov Ridge. Basin Res. doi: 10.1111/j.1365-2117.2009.00403.x

Rudels B, Jones EP, Anderson LG, Kattner G (1994) On the intermediate depth waters of the Arctic Ocean. In: Johannessen OM, Munch RD, Overland JE (eds) The Polar Oceans and their role in shapinng the global environment. Am. Geophys Un Momograph 85, Am Geophys Union, Washington DC20009, USA, pp 33-46

Sangiorgi F, Brumsack HJ, Willard DA, Schouten S, Stickley CE, O’Regan M, Reichart, GJ, Damste JSS, Brinkhuis H (2008) A 26 million year gap in the central Arctic record at the greenhouseicehouse transition: Looking for clues: paleoceanography 23. PA1S04. doi:10.1029/2007PA001477

Sageman BB, Arthur MA (1994) Early Turonian paleogeographic/ plaeobathymetric map, western Interior, U.S. In: Caputo MV, Peterson A, Franczyk KJ (eds) Mesozoic systems of the rocky mountain region. US, Tulsa Society of Economic Paleontologists And Mineralogists, pp 457-469

Sekretov SB (2001) Northwestern margin of the East Siberian Sea, Russian Arctic; seismic stratigraphy, structure of the sedimentary cover and some remarks on the tectonic history. Tectonophysics 339:353-383

Sluijs A, Schouten S, Pagani M, Woltering M, Brinkhuis H, Damste JSS, Dickens GR, Huber M, Reichart GJ, Stein R, Matthiessen J, Lourens LJ, Pedentchouk N, Backman J, Moran K (2006) Subtropical Arctic Ocean temperatures during the palaeocene/ eocene thermal maximum. Nature 441:610-613

Sorokin MY, Zamansky YY, AY Langinen, Jackson HR, Macnab R (1999) Crustal structure of the Makarov Basin, Arctic Ocean determined by seismic refraction. Earth Planet Sci Lett 168: 187-199

Stein R, Boucsein B, Meyer H (2006) Anoxia and high primary production in the Paleogene central Arctic Ocean: first detailed records from Lomonosov Ridge: GeophysRes Let 33: L18606. doi:10.1029/2006GL026776

Stickley CE, Koc N, Brumsack H-J, Jordan RW, Suto I (2008) A siliceous microfossil view of middle Eocene Arcticpaleoenvironments: a window of biosilica production and preservation Paleoceanography. 23: PA1S14. doi:10.1029/2007PA001485

Stow DAV, Faugères JC, Howe JA, Pudsey CJ, Viana AR (2002) Bottom currents, contourites and deep-sea sediment drifts; current state-of-the-art. In: Stow DAV, Pudsey CJ, Howe JA, Faugères JC, Viana, AR(ed) deep-water contourite systems: modern drifts and ancient series, seismic and sedimentary characteristics. Memoirs of the geological society of London 22, 7-20

Talwani M, Eldholm O (1977) Evolution of the Norwegian-Greenland Sea. Geol Soc Am Bull 88:969-999

Van Wagoner NA, Williamson MC (1985) Tectonic evolution of the Alpha Ridge; geochemical constraints. Geophysics 50:1363

Vogt PR, Taylor P, Kovacs LC, Johnson GL (1979) Detailed aeromagnetic investigation of the Arctic Basin. J Geophys Res 84:1071-1089

Waddell LM, Moore TC (2008) Salinity of the Eocene Arctic Ocean from oxygen isotope analysis of fish bone carbonate: paleoceanography 23: PA1S12. doi:10.1029/2007PA001451

Weber JR (1990) The structures of the Alpha Ridge, Arctic Ocean and Iceland-Faeroe Ridge, North Atlantic; comparisons and implications for the evolution of the Canada Basin. Mar Geol 93: $43-68$

Woodgate RA, Aagaard K, Muench R, Gunn J, Bjørk G, Rudels B, Roach AT, Schauer U (2001) The Arctic Ocean boundary current along the Eurasian slope and the adjacent Lomonosov Ridge: water mass properties, transports and transformations from moored instruments. Deep Sea Res Part I 48:1757-1792

Woodgate RA, Aagaard K, Swift JH, Smethie WM, Falkner KK (2007) Atlantic water circulation over the Mendeleev Ridge and Chukchi Borderland from thermohaline intrusions and water mass properties. J Geophys Res 112:C02005. doi:10.1029/ 2005JC003416 